\title{
Sosyal Bilgiler Öğretmen Adaylarının Kadına Yönelik Algılarının Çeşitli Değişkenler Açısından İncelenmesi ${ }^{1}$
}

\author{
Melek KÖRÜKCÜ${ }^{2}$, Salih USLU ${ }^{3}$ ve Mehmet ÇETINN ${ }^{4}$
}

Öz

Kadın ve erkek ayrımı tarih boyunca insanoğlunun en temel kategorize edilme biçimi olmuştur. Cinsiyet biyolojik özelliklerin yanı sıra doğumdan itibaren toplumsal kategori olarak anlamlandırılır. Bu çalışmada sosyal bilgiler öğretmen adaylarının (SBÖA) kadına yönelik algıları çeşitli değişkenler açısından incelenmiştir. Araştırmada yöntemi ilişkisel tarama yöntemi kullanılmıștır. Araştırmada, veri toplama aracı olarak araştırmacılar tarafindan hazırlanan "Kişisel Bilgi Formu” ile Gülmez, İra, Yılmaz ve Özenç İra (2017) tarafından geliştirilen "Üniversite Öğrencilerinde Kadın Algısı Ölçeği” kullanılmıştır. Araştırmaya; 151 kadın, 98 erkek toplam 249 sosyal bilgiler öğretmen adayı katılmıştır. Çalışma grubu, basit seçkisiz yöntemle ve gönüllük esasına bağlı olarak seçilmiştir. Elde edilen sonuçlar doğrultusunda, öğretmen adayları arasında kadın algısının, kadın adaylarda daha yüksek olduğu belirlenmiştir. Anne ve baba eğitim düzeyi değişkenine göre anlamlı bir farklılık bulunmazken; kadının toplumsal yaşamdaki kayıpları faktör boyutunda baba eğitim düzeyine göre anlamlı farklılık olduğu görülmüştür. Araştırmanın sonuçları sosyal bilgiler öğretmen adaylarının kadın algılarını ortaya koyması noktasında önemlidir.

Anahtar Kelimeler: Cinsiyet rolü, Kadın algısı, Sosyal bilgiler öğretmen adayı

\section{The Investigation of the Perceptions of Social Studies Teacher Candidates towards}

\section{Woman}

\begin{abstract}
The distinction between men and women has been the most basic categorization of mankind throughout history. In addition to biological characteristics, gender is understood as a social category from birth. In this study, the perceptions of the social science teacher candidates (SSTC) to the woman were examined in terms of various variables. Research is a descriptive study. The research was conducted in a relational screening model. Research; 151 female, 98 male and 249 social science teacher candidates participated. According to the results obtained, it was determined that female perception among teacher candidates is higher in female candidates. While no significant difference was found between parents and the education level variable; Women's losses in social life were found to be significantly different in the factor dimension compared to the father education level. The results of the research are important in the point that social science teacher candidates reveal female perceptions.
\end{abstract}

Key Words: Gender role, Perception of women, Social studies teacher candidate

\section{Atıf İçin / Please Cite As:}

Körükcü, M., Uslu, S. ve Çetin, M. (2020). Sosyal bilgiler öğretmen adaylarının kadına yönelik algılarının çeşitli değişkenler açısından incelenmesi. Manas Sosyal Araștırmalar Dergisi, 9(3), 1461-1478.

Geliş Tarihi / Received Date: 05.11.2019

Kabul Tarihi / Accepted Date: 17.04.2020

\footnotetext{
${ }^{1}$ Bu çalışma, 31 Ocak-2 Şubat 2018 tarihlerinde yapılan USBIK 2018 I. Uluslararası Sosyal Bilimler Kongresinde sözlü bildiri olarak sunuldu.

${ }^{2}$ Dr. Öğr. Üyesi. - Niğde Ömer Halisdemir Üniversitesi Eğitim Fakültesi, melekkorukcu@ohu.edu.tr ORCID: 0000-0002-7824-3497

3 Doç. Dr. - Niğde Ömer Halisdemir Üniversitesi Eğitim Fakültesi, salihuslu@ohu.edu.tr ORCID: 0000-0003-0558-516x

${ }^{4}$ Doktora Öğrencisi - Niğde Ömer Halisdemir Üniversitesi Eğitim Bilimleri Enstitüsü, mhmt.cetin10@gmail.com ORCID: 0000-0002-3065-1969
} 


\section{Giriş}

İnsanın kaderi daha doğmadan mı çiziliyordu? Erkeklik doğası kaderle mi belirleniyordu? Kız çocukoğlan çocuk ayrımı daha doğmadan yapılmıyor muydu? Bu soru sorulduğunda verilen cevap hayırlısıyla doğsun da kız da bizim oğlanda bizim değil miydi? Bu yanıtı belirleyen neydi? Belki de anne oğlu olursa ilerde ona bakıp bakmayacağını, kızının ise her daim yardımcısı olacağını düşünüyordu; babası ise oğlu olursa soyadını sürdürür, kızım olursa evlenip gider olarak mı düşünüyordu? Aslında bu düşüncenin altında ekonomik gerekçeler yok muydu? (Akar, 2018, s. 51). Bu düşüncenin altında ekonomik gerçeklerin yanı sıra biyolojik ve sosyolojik gerçekler de yer almaktadır. Biyolojik kökene dayanan kadın ve erkek terimi tüm dünyada iki cinsi birbirinden ayırmak için kullanılmaktadır. Sosyolojik açıdan toplum içerisinde kadın ve erkeğe ait kimliği sosyal ve kültürel açıdan tanımlamakta, aradaki farkları belirlemekte ve bu kimliklere yüklenen anlamları açıklamaktadır. Çünkü birey dünyaya geldiği andan itibaren o toplumun değerleri, davranış biçimleri, rolleri ve görevleri ile çevrelenir. Cinsiyet, her ne kadar doğuştan getirilse de toplumsal süreç içerisinde üzerine çeşitli anlamlar yüklenir. Bu nedenle kadınlık ve erkeklik toplumsallaşma sürecinde kültürel yapılanmanın olguları haline gelmiştir. Kadın veya erkek olma, biyolojik farklilıktan öte toplumun bizi nasıl gördüğü, nasıl algıladığı ve bu algılar karşısında nasıl davranmamızı istediği durumların toplamıdır. Toplumsal yapının insan ilişkilerini oluşturan ve bu ilişkileri kuşatan görünümü içerisinde bireyler, kadın ve erkek olarak toplumsal hayatın en temel karakteristik yapisinı meydana getirirler (Connell, 2016, s. 46).

Kadın; tarihin ilk çağlarından itibaren ev ile özdeşleştirilmiş, kamusal alandan uzak tutulmuş, kız çocuklarının kapasitesi erkek çocuklara oranla kısıtlanmış ve engellenmiştir. Orta çağın karanlığından çıkmaya çalışan kadın, aydınlanma çağı ile birlikte varlı̆̆ını kabul ettirmeye çalışıştır. Mary Wollstonecraft, feminist teori tarihindeki ilk önemli çalışma olan "Kadın Haklarının Gerekçelendirilmesi" isimli eserini günümüzden tam 226 y1l önce kaleme almıştır. Wollstonecraft, 38 yıllık ömründe, kendisinden sonraki yüzyılları, felsefe ve kadın hakları alanında yazdığı yazılar ile etkilemiştir. Kadın hakları konusunda temel aldığı sav, kadın ve erkeğin bilgi ve erdem konusunda eşit olması gerektiğidir. O'na göre; bir toplumda çocuklar yurtsever olarak yetiştirilmek isteniyorsa öncelikle annelerin yurtsever olmas1 gerekmektedir. Birçok erdemin kaynağı olan insanlık sevgisi; ancak insanluğın ahlaki ve sivil çıkarları üzerine düşünülerek üretilebilir. Bu durumun gerçekleşebilmesi için kadınların eğitimi ve sosyal konumu onları bu tür düşüncelerin uzağında tutmamalıdır (Wollstonecraft, 2012, s. 81). Büyük toplumsal değişmelerin yaşandığ1 19. Yüzyılda August Bebel (1996); kadın sorununu diğer toplumsal sorunlarla eşit görmüştür. Bebel'e göre (1996, s. 91-93) kadınların sorunları; toplumsal düzen içerisinde kadının yerinin ne olduğu, kadınlanın yeteneklerini ne şekilde geliştireceği ve kadınlara erkeler ile eşit haklar verilmesidir. Kadın sorununun özel bir araştırma gerektirdiğine vurgu yapan Bebel; kadının yeri ne idi, bugün nedir, yarın ne olacaktır soruları ile insanlığın yarısının uğraştığını belirtmiştir. Kadınlar Aydınlanma döneminde Fransız İhtilali ile halk meclisinde yer almak istemişlerdir. Bu istek, isteği dile getiren kişinin Olympe de Gouges'in giyotinle idam edilerek cezalandırılması ile sonuçlanmıştır. Yaşanan olumsuzluklar kadınların 'ben buradayım' demesini durduramamıştır. Endüstri devrimi ile sosyal haklar kazanmaya başlayan kadınlar 80 'ler sonrasında görülür hale gelmeye başlamıştır. Çok zorlu mücadeleler verilerek yazılan kadınlık tarihine ve kadının tanımına dair çalışmalar 20. yüzyıldan itibaren artış göstermiştir (Temelkuran, 2013, s. 190; Sarper, 2015, s. 4).

Kadınlık ve erkeklik toplumsal olarak öğrenilen kalıp yargılardır. Bu kalıp yargılardan kurtulmak için 21. yüzyılda, dünya genelinde ülkeler; yönetim, eğitim, kültürel, sosyal boyutlarda kadınlarla ilgili konuları kalkınma politikaları içerisine almaktadır. Bu konjonktürde, ülkemizde kadınlarla ilgili çalsşmalar yapılmaktadır. Cinsiyet eşitliği bir devlet politikası olarak uygulanmakta ve cinsiyet ayrımcillğı ortadan kaldırılmaya çalışılmaktadır. Binyıl kalkınma hedefleri (2018)'nin genişletilmiş hali olan ve Türkiye'nin de 2030'a kadar gerçekleştirmeyi taahhüt ettiği sürdürülebilir kalkınma hedeflerinden beşincisi; toplumsal cinsiyet eşitliğini sağlamak, tüm kadın ve kız çocuklarını güçlendirmek olarak belirlenmiştir. Bu kapsamdaki alt hedeflerden birisi de kadınlara ve kız çocuklarına yönelik her türlü ayrımcılığın her yerde bitirilmesidir. Kadının Statüsü Genel Müdürlügü koordinasyonunda "Kadına Yönelik Şiddetle Mücadele Ulusal Eylem Planı (2016-2020)" hazırlanmıştır. Bu plan ile mevzuat düzenlemeleri, farkındalık yaratma ve zihniyet dönüşümü, koruyucu, önleyici hizmet sunumu ve şiddet mağdurlarının güçlenmesi, sağlık hizmetlerinin düzenlenmesi ve uygulanması, kurum kuruluşlar arası işbirliği ve politika olmak üzere 5 temel alanda iyileştirmeler hedeflenmektedir (Kadına Yönelik Şiddetle Mücadele Ulusal Eylem Planı, [KYŞMUEP], 2016). Kadının Güçlenmesi Strateji Belgesi ve Eylem Planı 2018-2023 (2018) kadınların güçlenmesi adına 
5 temel politika eksenini içermektedir. Bunlar; eğitim, ekonomi, sağlık, karar alma mekanizmalarına katilım, medyadır.

Erkekliğin oluşumunda önemli bir faktör olan cinsiyet rejimine okullarda sıklıkla rastlanmaktadır. Çünkü okullar açık toplumsal cinsiyet rejimlerine sahip olan kurumlardır (Connell, 2016, s. 91). Günümüzde, dönüştürücü ve reformist eğitim, toplumsal yapıyı, tüm bireyler için daha demokratik bir yapıya ulaştırma amacındadır (Yazıc1, 2011, s. 167). Milli Eğitim Bakanlığı’nın eğitimde fırsat eşitliği politikası; eğitimde kadın, erkek herkese firsat ve imkân eşitliği sağlanması yönündedir (Milli Eğitim Temel Kanunu, 2018, s. 2). Okullarda, ilçe ve il düzeyinde yönetici kadrolarında toplumsal cinsiyet eşitliğinin sağlanması ve toplumsal cinsiyete ilişkin ayrımcı değerlerin değiştirilmesine yönelik, ulusal çapta çalışmalar yapılmaktadır (Unicef, 2015, s. 14). Müfredatta cinsiyetçiliğe yer verilmemesine rağmen "iyi, sessiz ve başarılı kız" ve "sert, asi ve delikanlı" gibi basmakalıp söylemler öğretmen tutumlarında okul ortamında ve çeşitli etkinliklerde açığa çıkabilmektedir (European Commission, 2009, Akt. Sayılan, 2012, s. 14-18). Sosyal bilgiler öğretim programında [SBÖP] (2018, s.16) 4. sınıf "Etkin vatandaşlık" ünitesinde "SB.4.6.1. Çocuk olarak sahip olduğu haklara örnekler verir." "SB.4.6.2. Aile ve okul yaşamındaki söz ve eylemlerinin sorumluluğunu alır." 6. sınıf "Etkin vatandaşlık" ünitesinde "SB.6.6.6. Türk tarihinden ve güncel örneklerden yola çıkarak toplumsal hayatta kadına verilen değeri fark eder." SBÖP (2018, S.22), 7. sınıf "Etkin vatandaşlık" ünitesinde "SB.5.6.3. Temel hakları ve bu hakları kullanmanın önemini açıklar." kazanımları yer almaktadır. İlgili kazanımlar ile eşitlik, adalet, sosyal katılım, siyasi katılım, çocuk hakları, insan hakları, pozitif ayrımcllı, ekonomik, siyasal ve toplumsal temsil gibi olumlu, kadına şiddet ve cinsiyet ayrımcilı̆̆ gibi olumsuz konular üzerinde durulması, belirtilmiştir. Bu konuların öğrencilere doğru ve etkili bir şekilde aktarılması ve öğretilmesi noktasında sosyal bilgiler öğretmenlerine önemli görevler düşmektedir. Öğrencilere rol model olacak olan öğretmenlerin cinsiyetleri, yaşları, eğitimleri, yetiştikleri ailenin ve toplumun genel yapısı onların cinsiyetlere bakış açılarını etkilemektedir (Acker, 1988, s. 307). Bu kapsamda araştırmanın ana amacı; sosyal bilgiler öğretmen adaylarının (SBÖA) kadına yönelik algılarının çeşitli değişkenler açısından incelenmesidir. Bu ana amaç kapsamında araştırmanın problem cümlesi sosyal bilgiler öğretmen adaylarının kadına yönelik algıları nasıldır? olarak belirlenmiştir. Araştırmanın alt problemleri ise şunlardir:

- Cinsiyetlerine göre değişmekte midir?

- Öğrenim görmekte oldukları sınıf düzeylerine göre değişmekte midir?

- Yaş düzeylerine göre değişmekte midir?

- Kardeş sayısına göre değişmekte midir?

- Aile tipine göre değişmekte midir?

- Doğum yerlerine göre değişmekte midir?

- İkamet ettikleri yere göre değişmekte midir?

- Anne ve baba eğitim düzeyine göre değişmekte midir?

- Anne ve baba meslek durumuna göre değişmekte midir?

\section{Yöntem}

$\mathrm{Bu}$ araştırma, sosyal bilgiler öğretmen adaylarının kadına yönelik algılarını belirlemeye çalışan betimsel bir çalsşmadır. Araştırma ilişkisel tarama modelinde yürütülmüştür. Tarama modelleri, geçmişte var olan ya da hâlen devam eden bir durumu var olduğu şekliyle betimlemeyi amaçlayan araştırma yaklaşımlarıdır. Araştırmaya konusu olan olay, birey ya da nesne, kendi koşulları içinde ele alınarak olduğu gibi tanımlanmaya çalışılır. Değiştirme ve etkileme çabası içine girilmeden, araştırılan konu uygun bir biçimde gözlenip belirlenir (Karasar, 2014, s. 77).

\section{Evren - Örneklem}

$\mathrm{Bu}$ araştırmanın çalışma grubunu; İç Anadolu bölgesinde, bir devlet üniversitesinde, Eğitim Fakültesi Sosyal Bilgiler Eğitimi Ana Bilim Dalında öğrenimlerini sürdüren, 151 kadın, 98 erkek olmak üzere toplamda 249 sosyal bilgiler öğretmen adayı oluşturmaktadır. Çalışma grubu, basit seçkisiz yöntemle ve gönüllük esasına bağlı olarak seçilmiştir. Seçkisiz örnekleme, bir örneklemin seçiminde kullanılan bir teknik olup, tanımlanmış bir evrendeki tüm elemanlara, örnekleme seçilmek için eşit ve birbirinden bağımsız şans verme olup; diğer bir deyişle tüm elemanlanın seçilme olasılığ aynıdır ve bir elemanın seçimi diğer elemanın seçimini etkilememektedir (Özen ve Gül, 2007, s. 399). 


\section{Veri Toplama Araçları}

Bu araştırmada, veri toplama aracı olarak araştırmacılar tarafından hazırlanan "Kişisel Bilgi Formu" ile Gülmez, İra, Yılmaz ve Özenç İra (2017) tarafindan geliştirilen "Üniversite Öğrencilerinde Kadın Algısı1 Ölçeği” kullanılmıştır. Kişisel Bilgi Formu: Kişisel bilgi formu, araştırmacılar tarafindan hazırlanmıştır. Formda, katılımcıların cinsiyet, öğrenim görmekte olunan sınıf düzeyi, yaş, kardeş sayıs1, aile tipi, doğum yeri, yerleşim yeri, anne eğitim durumu, baba eğitim durumu, anne meslek durumu ve baba meslek durumu değişkenleri yer almaktadır.

Üniversite Ögrencilerinde Kadın Algısı Ölçeği: Ölçek Gülmez, İra, Yılmaz ve Özenç İra (2017) tarafindan geliştirilmiştir. Ölçek beşli likert tipindedir. 33 maddeden oluşan ölçeğin alt faktörleri ise kadına yönelik ön kabuller, kadının toplumsal yaşamdaki kazanımları, kadının toplumsal yaşamdaki kayıplanı, Türkiye'de kadının statüsü, kadınların yaşadıkları sorunlarla ilgili çözüm önerileri şeklindedir. Ölçeğin tamamından elde edilen puanlar için hesaplanan alfa iç tutarlılık katsayısının. 84 olması, kabul edilebilir düzeyin üstünde olduğunu göstermektedir. Ölçeğin yapı geçerliliğini belirlemek için temel bileşenler analizi ve varimax dik döndürme yapılmıştır. Faktör analizi sonucunda toplam varyansın \%61,139'unu açılayan ve özdeğeri (eigenvalue) 1,00’’n üzerinde 5 faktörlü bir yapı elde edilmiştir. Uygulanan T- testinde ,029'luk bir fark oluşmuştur (Gülmez, İra, Yılmaz ve Özenç İra, 2017). Üniversite öğrencilerinde kadın alg1sı ölçeğinin, çalısma grubuna uygulanması ile elde edilen cronbach alpha değerleri; .75 olarak hesaplanmıştır.

\section{Verilerin Analizi}

Araştırmada tarama modeli esas alınmıştır. Sosyal bilgiler öğretmen adaylarının kadın algıları düzey puanları betimsel istatistik uygulamaları ile tespit edilmiştir. Sosyal bilgiler öğretmen adaylarının veri toplama aracındaki sorulara verdikleri cevaplara ilisskin aritmetik ortalama puanlarının hesaplanmasında; Hiç Katılmıyorum $(1.00<\mathrm{X} \leq 1.79)$, Katılmıyorum $(1.80<\mathrm{X} \leq 2.59)$, Kısmen Katıliyorum $(2.60<\mathrm{X}$ $\leq 3.39)$, Katıliyorum $(3.40<\mathrm{X} \leq 4.19)$, Tamamen Katılıyorum $(4.20<\mathrm{X} \leq 5.00)$ aralıkları esas alınmıştır. Katılımcıların kadın algısı ölçeğinden aldıkları puanların cinsiyet, yaş, anne ve baba meslek durumuna göre anlamlı farklılık gösterip göstermediği ilişkisiz örneklemler için t-testi ile belirlenmiştir. Katılımcıların kadın algısı ölçeğinden aldıkları puanların sınıf, kardeş sayısı, aile tipi, doğum yeri, yerleşim yeri, anne ve baba eğitim düzeyi değişkenlerine göre istatistiksel açıdan anlamlı bir farklılık gösterme durumları ise ilişkisiz örneklemler için tek faktörlü varyans analizi ile tespit edilmiştir. Söz konusu istatistiksel işlemler SPSS paket programı kullanılarak gerçekleştirilmiştir. Bu çalısmada anlamlılık düzeyi olarak $\mathrm{p} \leq .05$ kabul edilmiştir.

\section{Bulgular}

\section{Öğretmen Adaylarının Kadın Algısı Düzeyleri}

Tablo 1. Sosyal Bilgiler Ögretmen Adaylarmm Kadnn Algısı Düzeyleri Nasılder? Sorusuna İlişkin Bulgular

\begin{tabular}{|c|c|c|c|c|}
\hline $\begin{array}{l}\text { Madde } \\
\text { No }\end{array}$ & Madde & $n$ & $\overline{\boldsymbol{x}}$ & Düzey \\
\hline 1 & Kadının yeri, evidir. & 249 & 3.94 & Katıliyorum (Yüksek) \\
\hline 2 & Kadınlar tahrik etmezse erkekler taciz etmez. & 249 & 4.39 & Tamamen Katıliyorum (Çok Yüksek) \\
\hline 3 & Türkiye'de kadına karşı taciz ve tecavüz yaygındır. & 249 & 4.53 & Tamamen Katıliyorum (Çok Yüksek) \\
\hline 4 & Türkiye'de kadına karşı şiddet yaygındır. & 249 & 4.72 & Tamamen Katıliyorum (Çok Yüksek) \\
\hline 5 & Erkekler, kız kardeşlerini gerektiğinde dövebilmelidir. & 249 & 4.57 & Tamamen Katıliyorum (Çok Yüksek) \\
\hline 6 & Babalar, eşlerini dövebilirler. & 249 & 4.50 & Tamamen Katıliyorum (Çok Yüksek) \\
\hline 7 & Babalar, kızlarını dövebilirler. & 249 & 4.39 & Tamamen Katıliyorum (Çok Yüksek) \\
\hline 8 & Kadın, işsizliğin temel nedenlerinden biridir. & 249 & 4.00 & Katıliyorum (Yüksek) \\
\hline 9 & Kadın, her insan gibi din ve inanç özgürlüğüne sahiptir. & 249 & 3.72 & Katıliyorum (Yüksek) \\
\hline 10 & Türkiye'de kadının eğitimi yeterlidir. & 249 & 3.87 & Katıliyorum (Yüksek) \\
\hline 11 & Türkiye'de kadın, siyasette yeterince yer almaktadır. & 249 & 3.30 & Kısmen Katıliyorum (Orta) \\
\hline 12 & $\begin{array}{l}\text { Türkiye'de kadın, Avrupa ülkelerinden daha rahat ve } \\
\text { huzurludur. }\end{array}$ & 249 & 3.94 & Katılıyorum (Yüksek) \\
\hline 13 & Türkiye’de kadın, her türlü hak ve hukuka sahiptir. & 249 & 3.55 & Kat1liyorum (Yüksek) \\
\hline 14 & Türkiye’de kadınlar, bütün haklarını bilmektedir. & 249 & 3.09 & Kismen Katiliyorum (Orta) \\
\hline 15 & Türkiye'de kadın olmak bir ayrıcalıktır. & 249 & 2.84 & Kismen Katıliyorum (Orta) \\
\hline 16 & Türkiye’de kadınlar özgür değildir. & 249 & 3.45 & Katılıyorum (Yüksek) \\
\hline 17 & $\begin{array}{l}\text { Türkiye'de kadın olmanın zor olduğunu } \\
\text { düşünüyorum. }\end{array}$ & 249 & 3.00 & Kısmen Katıliyorum (Orta) \\
\hline 18 & Türkiye'de erkek egemen bir toplum yap1sı vardır. & 249 & 3.43 & Katıliyorum (Yüksek) \\
\hline
\end{tabular}


Tablo 1 - Devamı

\begin{tabular}{|c|c|c|c|c|}
\hline $\begin{array}{l}\text { Madde } \\
\text { No }\end{array}$ & Madde & $n$ & $\overline{\boldsymbol{x}}$ & Düzey \\
\hline 19 & $\begin{array}{l}\text { Türkiye'de kadın hakları konusunda ihlaller olduğuna } \\
\text { inaniyorum. }\end{array}$ & 249 & 3.54 & Katıllyorum (Yüksek) \\
\hline 20 & Kadına karşı şiddet uygulandığına tanık oldum. & 249 & 2.21 & Katılmıyorum (Düşük) \\
\hline 21 & $\begin{array}{l}\text { Töre cinayetleri, ailelerin kendi hukukunu kendilerinin } \\
\text { sağlama çabasıdır. }\end{array}$ & 249 & 2.11 & Katılmıyorum (Düşük) \\
\hline 22 & $\begin{array}{l}\text { Türkiye Cumhuriyeti kanunları, kadın hakları konusunda } \\
\text { demokratik değildir. }\end{array}$ & 249 & 2.17 & Katılmıyorum (Düşük) \\
\hline 23 & Kadınlarla ilgili konularda kurumlar arasında çatışma vardır. & 249 & 2.09 & Katılmıyorum (Düşük) \\
\hline 24 & Kadın hakları kuruluşları, dış odakların kontrolündedir. & 249 & 2.20 & Katılmiyorum (Düşük) \\
\hline 25 & Kadın hakları ile ilgili çalışmalar, verimsiz bir gayrettir. & 249 & 2.53 & Katılmıyorum (Düşük) \\
\hline 26 & $\begin{array}{l}\text { Kadınla ilgili sorunların çözümü için basın ve yayın } \\
\text { kuruluşları iyi kullanılmalıdır. }\end{array}$ & 249 & 4.44 & Tamamen Kattliyorum (Çok Yüksek) \\
\hline 27 & $\begin{array}{l}\text { Kadınla ilgili sorunların çözümü için kadın ve erkeğin } \\
\text { eğitimli olması gereklidir. }\end{array}$ & 249 & 4.37 & Tamamen Katıllyorum (Çok Yüksek) \\
\hline 28 & $\begin{array}{l}\text { Kadınla ilgili sorunların çözümü için zihniyet değişimi } \\
\text { gereklidir. }\end{array}$ & 249 & 4.40 & Tamamen Katiliyorum (Çok Yüksek) \\
\hline 29 & $\begin{array}{l}\text { Kadınla ilgili sorunların çözümü için anne ve baba eğitimi } \\
\text { gereklidir. }\end{array}$ & 249 & 4.44 & Tamamen Katıllyorum (Çok Yüksek) \\
\hline 30 & Kadınla ilgili sorunların çözümü için ekonomik özgürlük şarttır. & 249 & 4.38 & Tamamen Katılıyorum (Çok Yüksek) \\
\hline 31 & $\begin{array}{l}\text { TBMM'deki milletvekili sayısı, cinsiyet açısından, şimdiki } \\
\text { durumun tam tersi olursa sorunlar çözülür. }\end{array}$ & 249 & 4.00 & Katılıyorum (Yüksek) \\
\hline 32 & $\begin{array}{l}\text { Kadın hakları ile ilgili çalışmalar, konuyla ilgili } \\
\text { bilinçlenmeyi sağlar. }\end{array}$ & 249 & 4.37 & Tamamen Kattliyorum (Çok Yüksek) \\
\hline \multirow[t]{2}{*}{33} & $\begin{array}{l}\text { Mutluluğa giden yolun, kadına saygıdan geçtiği, bütün } \\
\text { bireylere öğretilmelidir. }\end{array}$ & 249 & 4.46 & Tamamen Kattlıyorum (Çok Yüksek) \\
\hline & Genel Ortalama & 249 & 3.66 & Katılıyorum (Yüksek) \\
\hline
\end{tabular}

Sosyal bilgiler öğretmen adaylarının kadın algısı ölçeğindeki sorulara verdikleri cevaplara ilişkin aritmetik ortalama puanlarının hesaplanmasında şu aralıklar temel alınmıştır: Hiç Katılmıyorum $(1.00<\overline{\mathrm{X}}$ $\leq 1.79)$, Katilmiyorum $(1.80<\overline{\mathrm{X}} \leq 2.59)$, Kismen Kat1liyorum $(2.60<\overline{\mathrm{X}} \leq 3.39)$, Kat1liyorum $(3.40<\overline{\mathrm{X}}$ $\leq 4.19)$, Tamamen Katılıyorum $(4.20<\mathrm{X} \leq 5.00)$. Tablo 1'deki analiz sonuçlarına göre:

Öğretmen adaylarının kadın algısı ölçeğine vermiş oldukları cevaplara ilişkin aritmetik puan ortalamalarının en düşük $(\overline{\mathrm{X}}=2.09)$ olduğu maddenin "Kadınlarla ilgili konularda kurumlar arasında çatısma vardır." maddesi (23. Madde) olduğu tespit edilmiştir. Kadın algısı ölçeğine verilen cevaplara ilişkin olarak aritmetik puan ortalamasının en yüksek olduğu maddenin $(\overline{\mathrm{X}}=4.72)$ ise "Türkiye'de kadına karşı şiddet yaygındır." (4. Madde) maddesi olduğu sonucuna ulaşılmıştır. Ölçeğin genelinde elde edilen aritmetik ortalama puanlarına bakıldığında ise $(\overline{\mathrm{X}}=3.66)$ öğretmen adaylarının kadın algılarının Katıllyorum (Yüksek) yüksek düzeyde olduğu tespit edilmiştir.

\section{Birinci Alt Probleme İlişkin Bulgular}

Tablo 2. Sosyal Bilgiler Öğretmen Adaylarmm Kadnn Algzlarna İlişkin Ölçek Ortalamalarmmn Cinsiyet Değğşkenine Göre Bağımsız t-Testi Sonuclar

\begin{tabular}{|c|c|c|c|c|c|c|c|}
\hline Faktörler & Cinsiyet & $\mathbf{n}$ & $\bar{X}$ & Ss & sd & t & $\mathrm{p}$ \\
\hline \multirow{2}{*}{ Kadına Yönelik Ön Kabuller } & Kadın & 151 & 32.61 & 2.89 & 247 & 7.972 & $.000^{*}$ \\
\hline & Erkek & 98 & 28.60 & 5.03 & & & \\
\hline \multirow{2}{*}{ Kadının Toplumsal Yaşamdaki Kazanımları } & Kadin & 151 & 23.57 & 4.20 & 247 & 5.274 & $.000^{*}$ \\
\hline & Erkek & 98 & 20.55 & 4.73 & & & \\
\hline \multirow{2}{*}{ Kadının Toplumsal Yaşamdaki Kayıpları } & Kadın & 151 & 18.50 & 4.38 & 247 & 4.318 & $.000^{*}$ \\
\hline & Erkek & 98 & 20.97 & 4.46 & & & \\
\hline \multirow{2}{*}{ Türkiye'de Kadının Statüsü } & Kadın & 151 & 12.48 & 4.84 & 247 & 3.268 & $.001^{*}$ \\
\hline & Erkek & 98 & 14.58 & 5.15 & & & \\
\hline \multirow{2}{*}{$\begin{array}{l}\text { Kadınların Yaşadıkları Sorunlarla İlgili Çözüm } \\
\text { Önerileri }\end{array}$} & Kadin & 151 & 35.65 & 5.30 & 247 & 2.458 & $.015^{*}$ \\
\hline & Erkek & 98 & 33.85 & 6.16 & & & \\
\hline \multirow{2}{*}{ Toplam } & Kadın & 151 & 122.80 & 8.53 & 247 & 3.566 & $.000^{*}$ \\
\hline & Erkek & 98 & 118.55 & 10.12 & & & \\
\hline
\end{tabular}


Tablo 2 incelendiğinde, sosyal bilgiler öğretmen adaylarının cinsiyetleri ile kadın algısı alt faktör düzeyleri arasında, Kadına Yönelik Ön Kabuller $\left(\mathrm{t}_{(247)}=7.972 ; \mathrm{p} \leq .05\right)$, Kadının Toplumsal Yaşamdaki Kazanımları $\left(\mathrm{t}_{(247)}=5.274 ; \mathrm{p} \leq .05\right)$, Kadının Toplumsal Yaşamdaki Kayıpları $\left(\mathrm{t}_{(247)}=4.318 ; \mathrm{p} \leq .05\right)$,

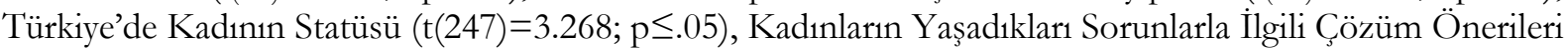
$\left(\mathrm{t}_{(247)}=2.458 ; \mathrm{p} \leq .05\right)$ faktörlerinde ve ölçeğin genelinde toplam puan açısından $\left(\mathrm{t}_{(247)}=3.566 ; \mathrm{p} \leq .05\right)$ anlaml bir farklılı̆̆ın olduğu görülmüştür. Elde edilen sonuçlar doğrultusunda sosyal bilgiler öğretmen adaylarının kadın algısı anlamlılık düzeyi, ölçeğin genel toplamında ve Kadına Yönelik Ön Kabuller, Kadının Toplumsal Yaşamdaki Kazanımları, Kadınların Yaşadıkları Sorunlarla İlgili Çözüm Önerileri alt faktörlerinde kadın öğretmen adaylarında yüksek iken, Kadının Toplumsal Yaşamdaki Kayıpları ve Türkiye'de Kadının Statüsü faktörlerinde erkek öğretmen adaylarının kadın algılarının yüksek olduğu görülmektedir.

\section{İkinci Alt Probleme İlişkin Bulgular}

Tablo 3. Sosyal Bilgiler Ögrretmen Adaylarmın Kadın Algısı Düzeylerine İlişkin Ölçek Ortalamalarmın Smıf Değişkenine Göre One-W ay ANOV A Sonuçlar

\begin{tabular}{|c|c|c|c|c|c|c|c|c|c|c|}
\hline Faktör & Sinif & $\mathbf{n}$ & $\bar{X}$ & Ss & VK & K'T & sd & KO & $\mathbf{F}$ & $\mathrm{p}$ \\
\hline \multirow{4}{*}{$\begin{array}{l}\text { Kadina } \\
\text { Yönelik Ön } \\
\text { Kabuller }\end{array}$} & 1. Sinif & 64 & 31.33 & 3.79 & Gruplar Aras1 & 369.177 & 3 & 123.059 & 7.020 & $.000^{*}$ \\
\hline & 2. Sinif & 72 & 31.44 & 4.07 & Gruplar İçi & 4294.566 & 245 & 17.529 & & \\
\hline & 3. Sinif & 80 & 31.70 & 3.76 & Toplam & 4663.743 & 248 & & & \\
\hline & 4 ve üzeri & 33 & 27.94 & 5.85 & \multicolumn{6}{|c|}{ Farkın Kaynağı (Scheffe): $1>4 ; 2>4 ; 3>4$} \\
\hline \multirow{4}{*}{$\begin{array}{l}\text { Kadının } \\
\text { Toplumsal } \\
\text { Yaşamdaki } \\
\text { Kazanımları }\end{array}$} & 1. Sinif & 64 & 21.89 & 5.05 & Gruplar Arası & 324.476 & 3 & 108.159 & 5.272 & $.002^{*}$ \\
\hline & 2. Sinif & 72 & 23.63 & 4.49 & Gruplar İçi & 5026.279 & 245 & 20.515 & & \\
\hline & 3. Sinif & 80 & 22.65 & 3.92 & Toplam & 5350.755 & 248 & & & \\
\hline & 4 ve üzeri & 33 & 19.97 & 4.93 & \multicolumn{6}{|c|}{ Farkın Kaynağı (Scheffe): 2>4; 3>4 } \\
\hline \multirow{4}{*}{$\begin{array}{l}\text { Kadının } \\
\text { Toplumsal } \\
\text { Yaşamdaki } \\
\text { Kayıpları }\end{array}$} & 1. Sinif & 64 & 19.69 & 4.71 & Gruplar Arası & 31.713 & 3 & 10.571 & .503 & .680 \\
\hline & 2. Sinif & 72 & 18.92 & 4.00 & Gruplar İçi & 5144.311 & 245 & 20.997 & & \\
\hline & 3. Sinif & 80 & 19.75 & 5.10 & Toplam & 5176.024 & 248 & & & \\
\hline & 4 ve üzeri & 33 & 19.58 & 4.18 & & & & & & \\
\hline \multirow{4}{*}{$\begin{array}{l}\text { Türkiye'de } \\
\text { Kadın Statüsü }\end{array}$} & 1. Sinif & 64 & 13.25 & 5.01 & Gruplar Aras1 & 175.763 & 3 & 58.588 & 2.324 & .076 \\
\hline & 2. Sinif & 72 & 14.10 & 5.96 & Gruplar İçi & 6177.040 & 245 & 25.212 & & \\
\hline & 3. Sinif & 80 & 12.21 & 3.94 & Toplam & 6352.803 & 248 & & & \\
\hline & 4 ve üzeri & 33 & 14.33 & 5.15 & & & & & & \\
\hline \multirow{4}{*}{$\begin{array}{l}\text { Kadınların } \\
\text { Yaşadıkları } \\
\text { Sorunlarla } \\
\text { İlgili Çözüm } \\
\text { Önerileri }\end{array}$} & 1. Sinif & 64 & 35.39 & 4.10 & Gruplar Aras1 & 465.484 & 3 & 155.161 & 4.990 & $.002^{*}$ \\
\hline & 2. Sinif & 72 & 33.13 & 7.94 & Gruplar İçi & 7618.612 & 245 & 31.096 & & \\
\hline & 3. Sinif & 80 & 36.51 & 3.64 & Toplam & 8084.096 & 248 & & & \\
\hline & 4 ve üzeri & 33 & 34.21 & 5.70 & \multicolumn{6}{|c|}{ Farkın Kaynağı (Scheffe): 3>2 } \\
\hline \multirow{4}{*}{ Toplam } & 1. Sinif & 64 & 121.55 & 6.96 & Gruplar Arası & 1099.633 & 3 & 366.544 & 4.312 & $.006^{*}$ \\
\hline & 2. Sinif & 72 & 121.21 & 10.25 & Gruplar İçi & 20824.254 & 245 & 84.997 & & \\
\hline & 3. Sinif & 80 & 122.83 & 9.70 & Toplam & 21923.888 & 248 & & & \\
\hline & 4 ve üzeri & 33 & 116.03 & 9.50 & \multicolumn{6}{|c|}{ Farkın Kaynağı (Scheffe): 3>4 } \\
\hline
\end{tabular}

Tablo 3 incelendiğinde sosyal bilgiler öğretmen adaylarının öğrenim gördükleri sınıf düzeyi ile kadın algisı düzeyleri arasında; ölçeğin genelinde toplam puan açısından $\left(\mathrm{F}_{(4-244)}=3.566 ; \mathrm{p} \leq .05\right)$ ve Kadına Yönelik Ön Kabuller $\left(\mathrm{F}_{(4-244)}=7.972 ; \mathrm{p} \leq .05\right)$, Kadının Toplumsal Yaşamdaki Kazanımları $\left(\mathrm{F}_{(4-244)}=5.274\right.$; $\mathrm{p} \leq .05)$, Kadınların Yaşadıkları Sorunlarla İlgili Çözüm Önerileri $\left(\mathrm{F}_{(4-244)}=2.458 ; \mathrm{p} \leq .05\right)$ faktörlerinde istatistiksel açıdan anlamlı bir farklılığın olduğu, Kadının Toplumsal Yaşamdaki Kayıpları $\left(\mathrm{F}_{(4-244)}=-4.318\right.$; p>.05) ve Türkiye'de Kadının Statüsü $\left(\mathrm{F}_{(4-244)}=-3.268\right.$; $\left.\mathrm{p}>.05\right)$ faktörlerinde ise anlamlı bir farklilı̆ı̆n olmadığı görülmüştür. Ölçeğin genelinde toplam puan açısından anlamlılık düzeyinin 3. sınıfta öğrenim görmekte olan öğretmen adayları lehine $(\bar{X}=122.83)$ olduğu, 4 ve üzeri sınıf düzeyinde öğrenim görmekte olan öğretmen adaylarının 3. sınıfta öğrenim görmekte olan öğretmen adaylarına kıyasla kadın algısı düzeylerinin daha düşük $(\bar{X}=116.03)$ olduğu tespit edilmiştir. Kadına Yönelik Ön Kabuller faktöründe 4 ve üzeri sınıf düzeyinde öğrenim görmekte olan öğretmen adaylarının 1. 2. ve 3. sınıf düzeyinde öğrenim görmekte olan öğretmen adaylarına kıyasla kadına yönelik ön kabul düzeylerinin daha yüksek olduğu sonucuna ulaşılmıştır. Kadının Toplumsal Yaşamdaki Kazanımları faktöründe 2. ve 3. sınıf düzeyinde öğrenim gören öğretmen adaylarının kadının toplumsal yaşamdaki kazanımlarına yönelik düzeylerinin 4 ve 
üzeri sınıf düzeyinde öğrenim görmekte olan öğretmen adaylarına kıyasla daha yüksek olduğu tespit edilmiştir. Kadınların Yaşadıkları Sorunlarla İlgili Çözüm Önerileri faktöründe ise 3. Sınıfta öğrenim görmekte olan öğretmen adaylarının kadınların yaşadıkları sorunlarla ilgili çözüm önerileri düzeylerinin 2. Sınıf düzeyinde öğrenim görmekte olan öğretmen adaylarına kıyasla daha yüksek olduğu tespit edilmiştir.

\section{Üçüncü Alt Probleme İlişkin Bulgular}

Tablo 4. Sosyal Bilgiler Öğretmen Adaylarnn Kadın Algularna İlişkin Ölçek Ortalamalarmn Yaş Değğşkenine Göre Bağımsiz t-Testi Sonuclar

\begin{tabular}{|c|c|c|c|c|c|c|c|}
\hline Faktörler & Yaş & n & $\bar{X}$ & Ss & sd & $\mathbf{t}$ & $\mathrm{p}$ \\
\hline \multirow{2}{*}{ Kadına Yönelik Ön Kabuller } & 20 Yaş ve Altı & 135 & 31.91 & 3.56 & \multirow[t]{2}{*}{247} & \multirow[t]{2}{*}{3.562} & \multirow[t]{2}{*}{$.000^{*}$} \\
\hline & 21 Yaş ve Üzeri & 114 & 29.99 & 4.92 & & & \\
\hline \multirow{2}{*}{$\begin{array}{l}\text { Kadının Toplumsal Yaşamdaki } \\
\text { Kazanımları }\end{array}$} & 20 Yaş ve Altı & 135 & 22.79 & 4.50 & \multirow[t]{2}{*}{247} & \multirow[t]{2}{*}{1.524} & \multirow[t]{2}{*}{.129} \\
\hline & 21 Yaş ve Üzeri & 114 & 21.89 & 4.79 & & & \\
\hline \multirow{2}{*}{$\begin{array}{l}\text { Kadının Toplumsal Yaşamdaki } \\
\text { Kayıpları }\end{array}$} & 20 Yaş ve Alt1 & 135 & 19.50 & 4.94 & \multirow[t]{2}{*}{247} & \multirow[t]{2}{*}{.127} & \multirow[t]{2}{*}{.899} \\
\hline & 21 Yaș ve Üzeri & 114 & 19.43 & 4.10 & & & \\
\hline \multirow{2}{*}{ Türkiye'de Kadının Statüsü } & 20 Yaş ve Altı & 135 & 12.90 & 5.12 & \multirow[t]{2}{*}{247} & \multirow[t]{2}{*}{1.365} & \multirow[t]{2}{*}{.174} \\
\hline & 21 Yaș ve Üzeri & 114 & 13.78 & 4.98 & & & \\
\hline \multirow{2}{*}{$\begin{array}{l}\text { Kadınların Yaşadıkları Sorunlarla } \\
\text { İlgili Çözüm Önerileri }\end{array}$} & 20 Yaş ve Alt1 & 135 & 35.20 & 5.56 & \multirow[t]{2}{*}{247} & \multirow[t]{2}{*}{.782} & \multirow[t]{2}{*}{.435} \\
\hline & 21 Yaş ve Üzeri & 114 & 34.63 & 5.89 & & & \\
\hline \multirow{2}{*}{ Toplam } & 20 Yaş ve Alt1 & 135 & 122.31 & 9.15 & \multirow[t]{2}{*}{247} & \multirow[t]{2}{*}{2.176} & \multirow[t]{2}{*}{$.031 *$} \\
\hline & 21 Yaş ve Üzeri & 114 & 119.73 & 9.55 & & & \\
\hline
\end{tabular}

${ }^{*} \mathrm{p} \leq .05$

Tablo 4 incelendiğinde, sosyal bilgiler öğretmen adaylanının yaş değişkeni ile kadın algısı alt faktör düzeyleri arasında, Kadının Toplumsal Yaşamdaki Kazanımlanı $\left(\mathrm{t}_{(247)}=1.524 ; \mathrm{p}>.05\right)$, Kadının Toplumsal Yaşamdaki Kayıpları $\left(\mathrm{t}_{(247)}=.127 ; \mathrm{p}>.05\right)$, Türkiye'de Kadının Statüsü $\left(\mathrm{t}_{(247)}=1.365 ; \mathrm{p}>.05\right)$, Kadınların Yaşadıkları Sorunlarla İlgili Çözüm Önerileri $\left(\mathrm{t}_{(247)}=.435 ; \mathrm{p}>.05\right)$ faktörlerinde anlamlı bir farklılık bulunmazken; Kadına Yönelik Ön Kabuller $\left(\mathrm{t}_{(247)}=3.562 ; \mathrm{p}<.05\right)$, ve ölçeğin genelinde toplam puan açısından $\left(\mathrm{t}_{(247)}=2.76 ; \mathrm{p}<.05\right)$ anlamlı bir farklilı̆̆ı olduğu görülmüştür. Elde edilen sonuçlar doğrultusunda sosyal bilgiler öğretmen adaylarının kadın algısı anlamlılık düzeyi, Kadına Yönelik Ön Kabuller ile ölçeğin genel toplamında ve 20 yaş ve altı öğretmen adaylarında $(\bar{X}=31.91),(\bar{X}=122.31) 21$ yaş ve üzeri öğretmen adaylarına kıyasla $(\bar{X}=29.99),(\bar{X}=119.73)$ daha yüksek olduğu sonucuna ulaşılmıştır. $\mathrm{Bu}$ durum 21 yaş ve üzerinde ergenlik sürecinin sona ermesi ve cinsiyet kavramının oturmasından dolayı cinsiyetçi bakış açılarının azalmaya başlamasının etkili olduğu şeklinde yorumlanabilir.

\section{Dördüncü Alt Probleme İlişkin Bulgular}

Tablo 5 incelendiğinde, sosyal bilgiler öğretmen adaylarının kardeş sayısı ile kadın algısı düzeyleri arasında, Kadına Yönelik Ön Kabuller $\left(\mathrm{F}_{(3-245)}=.216\right.$; p >.05), Kadının Toplumsal Yaşamdaki Kazanımları $\left(\mathrm{F}_{(3-245)}=.655 ; \mathrm{p}>.05\right)$, Kadının Toplumsal Yaşamdaki Kayıpları $\left(\mathrm{F}_{(3-245)}=.146 ; \mathrm{p}>.05\right)$, Türkiye'de Kadının Statüsü $\left(\mathrm{F}_{(3-245)}=.575 ; \mathrm{p}>.05\right)$ Kadınların Yaşadıkları Sorunlarla İlgili Çözüm Önerileri $\left(\mathrm{F}_{(3-245)}=1.723\right.$; $\mathrm{p}>$.05) faktörlerinde ve ölçeğin genelinde toplam puan açısından $\left(\mathrm{F}_{(3-245)}=.524 ; \mathrm{p}>.05\right)$ anlamlı bir farklılık olmadığı görülmektedir. Elde edilen sonuçlar doğrultusunda sosyal bilgiler öğretmen adaylarının kadın algıları ile kardeş sayısı arasında bir ilişki olmadığı söylenebilir. 
KÖRÜKCÜ, USLU ve ÇETINN

Sosyal Bilgiler Öğretmen Adaylarının Kadına Yönelik Algılarının Çeşitli Değiş̧kenler Açısından İncelenmesi

Tablo 5. Sosyal Bilgiler Öğretmen Adaylarmın Kadın Algılarma İlişkin Ölçek Ortalamalarnın Kardeş Sayısı Değiskenine Göre One-W ay ANOV A Sonuclar

\begin{tabular}{|c|c|c|c|c|c|c|c|c|c|c|}
\hline Faktör & $\begin{array}{l}\text { Kardeş } \\
\text { Sayıs1 }\end{array}$ & $\mathbf{n}$ & $\bar{X}$ & Ss & VK & K'T & sd & KO & $\mathbf{F}$ & $\mathrm{p}$ \\
\hline $\begin{array}{l}\text { Kadına Yönelik } \\
\text { Ön Kabuller }\end{array}$ & $\begin{array}{l}\text { Kardeş Yok } \\
1 \text { Kardeş } \\
2 \text { Kardeş } \\
3 \text { ve Üzeri }\end{array}$ & $\begin{array}{c}6 \\
56 \\
58 \\
129\end{array}$ & $\begin{array}{l}31.17 \\
30.80 \\
31.41 \\
30.95\end{array}$ & $\begin{array}{l}4.79 \\
4.37 \\
4.31 \\
4.35 \\
\end{array}$ & $\begin{array}{l}\text { Gruplar Arası } \\
\text { Gruplar İçi } \\
\text { Toplam }\end{array}$ & $\begin{array}{c}12.280 \\
4651.463 \\
4663.743\end{array}$ & $\begin{array}{c}3 \\
245 \\
248\end{array}$ & $\begin{array}{c}4.093 \\
18.986\end{array}$ & .216 & .886 \\
\hline $\begin{array}{l}\text { Kadının } \\
\text { Toplumsal } \\
\text { Yaşamdaki } \\
\text { Kazanımları }\end{array}$ & $\begin{array}{l}\text { Kardeş Yok } \\
1 \text { Kardeş } \\
2 \text { Kardeş } \\
3 \text { ve Üzeri }\end{array}$ & $\begin{array}{c}6 \\
56 \\
58 \\
129 \\
\end{array}$ & $\begin{array}{l}25.00 \\
22.38 \\
22.34 \\
22.28 \\
\end{array}$ & $\begin{array}{l}4.56 \\
4.28 \\
4.89 \\
4.71 \\
\end{array}$ & $\begin{array}{l}\text { Gruplar Arası } \\
\text { Gruplar İçi } \\
\text { Toplam }\end{array}$ & $\begin{array}{c}42.573 \\
5308.182 \\
5350.755\end{array}$ & $\begin{array}{c}3 \\
245 \\
248\end{array}$ & $\begin{array}{l}14.191 \\
21.666\end{array}$ & .655 & .581 \\
\hline $\begin{array}{l}\text { Kadının } \\
\text { Toplumsal } \\
\text { Yaşamdaki } \\
\text { Kayıpları }\end{array}$ & $\begin{array}{l}\text { Kardeş Yok } \\
1 \text { Kardeş } \\
2 \text { Kardeş } \\
3 \text { ve Üzeri }\end{array}$ & $\begin{array}{c}6 \\
56 \\
58 \\
129\end{array}$ & $\begin{array}{l}18.67 \\
19.32 \\
19.34 \\
19.63\end{array}$ & $\begin{array}{l}4.93 \\
4.39 \\
4.55 \\
4.68 \\
\end{array}$ & $\begin{array}{l}\text { Gruplar Arası } \\
\text { Gruplar İçi } \\
\text { Toplam }\end{array}$ & $\begin{array}{c}9.233 \\
5166.791 \\
5176.024\end{array}$ & $\begin{array}{c}3 \\
245 \\
248\end{array}$ & $\begin{array}{c}3.078 \\
21.089\end{array}$ & .146 & .932 \\
\hline $\begin{array}{l}\text { Türkiye'de } \\
\text { Kadın Statüsü }\end{array}$ & $\begin{array}{l}\text { Kardeş Yok } \\
1 \text { Kardeş } \\
2 \text { Kardeş } \\
3 \text { ve Üzeri }\end{array}$ & $\begin{array}{c}6 \\
56 \\
58 \\
129 \\
\end{array}$ & $\begin{array}{l}11.17 \\
13.59 \\
13.67 \\
13.12 \\
\end{array}$ & $\begin{array}{l}2.48 \\
5.00 \\
5.71 \\
4.88 \\
\end{array}$ & $\begin{array}{l}\text { Gruplar Arası } \\
\text { Gruplar İçi } \\
\text { Toplam }\end{array}$ & $\begin{array}{c}44.385 \\
6308.419 \\
6352.803\end{array}$ & $\begin{array}{c}4 \\
244 \\
248\end{array}$ & $\begin{array}{l}14.795 \\
25.749\end{array}$ & .575 & .632 \\
\hline $\begin{array}{l}\text { Kadınların } \\
\text { Yaşadıkları } \\
\text { Sorunlarla İlgili } \\
\text { Çözüm Önerileri }\end{array}$ & $\begin{array}{l}\text { Kardeş Yok } \\
1 \text { Kardeş } \\
2 \text { Kardeş } \\
3 \text { ve Üzeri }\end{array}$ & $\begin{array}{c}6 \\
56 \\
58 \\
129\end{array}$ & $\begin{array}{l}37.83 \\
33.84 \\
34.50 \\
35.48 \\
\end{array}$ & $\begin{array}{l}3.13 \\
6.86 \\
6.26 \\
4.88 \\
\end{array}$ & $\begin{array}{l}\text { Gruplar Arası } \\
\text { Gruplar İçi } \\
\text { Toplam }\end{array}$ & $\begin{array}{c}167.008 \\
7917.088 \\
8084.096\end{array}$ & $\begin{array}{c}3 \\
245 \\
248\end{array}$ & $\begin{array}{l}55.669 \\
32.315\end{array}$ & 1.723 & .163 \\
\hline Toplam & $\begin{array}{l}\text { Kardeş Yok } \\
1 \text { Kardeş } \\
2 \text { Kardeş } \\
3 \text { ve Üzeri }\end{array}$ & $\begin{array}{c}6 \\
56 \\
58 \\
129\end{array}$ & $\begin{array}{l}123.83 \\
119.93 \\
121.28 \\
121.46\end{array}$ & $\begin{array}{l}6.49 \\
9.37 \\
9.31 \\
9.61\end{array}$ & $\begin{array}{l}\text { Gruplar Arası } \\
\text { Gruplar İçi } \\
\text { Toplam }\end{array}$ & $\begin{array}{c}139.738 \\
21784.149 \\
21923.888\end{array}$ & $\begin{array}{c}3 \\
245 \\
248\end{array}$ & $\begin{array}{l}46.579 \\
88.915\end{array}$ & .524 & .666 \\
\hline
\end{tabular}

\section{Beşinci Alt Probleme İlişkin Bulgular}

Tablo 6. Sosyal Bilgiler Öğretmen Adaylarmm Kadın Algılarma İlişkin Ölçek Ortalamalarmın Aile Tipi Değişsenine Göre One-W ay ANOV A Sonuclar

\begin{tabular}{|c|c|c|c|c|c|c|c|c|c|c|}
\hline Faktör & Aile Tipi & $\mathrm{n}$ & $\bar{X}$ & Ss & VK & KT & sd & KO & $\mathbf{F}$ & $\mathrm{p}$ \\
\hline \multirow{3}{*}{$\begin{array}{l}\text { Kadina } \\
\text { Yönelik } \\
\text { Ön Kabuller }\end{array}$} & 1- Çekirdek Aile & 215 & 31.18 & 4.25 & Gruplar Aras1 & 65.238 & 2 & 32.619 & 1.745 & .177 \\
\hline & 2- Geniş Aile & 26 & 29.58 & 4.86 & Gruplar İçi & 4598.505 & 246 & 18.693 & & \\
\hline & 3- Parçalanmış Aile & 8 & 31.88 & 4.49 & Toplam & 4663.743 & 248 & & & \\
\hline \multirow{3}{*}{$\begin{array}{l}\text { Kadının } \\
\text { Toplumsal } \\
\text { Yaşamdaki } \\
\text { Kazanımları }\end{array}$} & 1- Çekirdek Aile & 215 & 22.47 & 4.54 & Gruplar Aras1 & 23.827 & 2 & 11.913 & .550 & .578 \\
\hline & 2- Geniş Aile & 26 & 21.50 & 5.59 & Gruplar İçi & 5326.928 & 246 & 21.654 & & \\
\hline & 3- Parçalanmış Aile & 8 & 22.88 & 4.42 & Toplam & 5350.755 & 248 & & & \\
\hline \multirow{3}{*}{$\begin{array}{l}\text { Kadının } \\
\text { Toplumsal } \\
\text { Yaşamdaki } \\
\text { Kayıpları }\end{array}$} & 1- Çekirdek Aile & 215 & 19.4326 & 4.70 & Gruplar Arası & 4.367 & 2 & 2.184 & .104 & .901 \\
\hline & 2- Geniş Aile & 26 & 19.8462 & 3.81 & Gruplar İçi & 5171.657 & 246 & 21.023 & & \\
\hline & 3- Parçalanmış Aile & 8 & 19.2500 & 3.49 & Toplam & 5176.024 & 248 & & & \\
\hline \multirow{4}{*}{$\begin{array}{l}\text { Türkiye'de } \\
\text { Kadın } \\
\text { Statüsü }\end{array}$} & 1- Çekirdek Aile & 215 & 13.08 & 4.98 & Gruplar Aras1 & 158.801 & 2 & 79.401 & 3.151 & $.044^{*}$ \\
\hline & 2- Geniş Aile & 26 & 15.58 & 5.68 & Gruplar İçi & 6194.002 & 246 & 25.179 & & \\
\hline & 3- Parçalanmış Aile & 8 & 12.00 & 3.38 & Toplam & 6352.803 & 248 & & & \\
\hline & 1- Çekirdek Aile & & \multicolumn{8}{|c|}{ Farkın Kaynağı (Scheffe): $2>1$} \\
\hline \multirow{4}{*}{$\begin{array}{l}\text { Kadınların } \\
\text { Yaşadıkları } \\
\text { Sorunlarla } \\
\text { İlgili Çözüm } \\
\text { Önerileri }\end{array}$} & 2- Geniş Aile & 215 & 35.23 & 5.35 & Gruplar Aras1 & 217.648 & 2 & 108.824 & 3.403 & $.035^{*}$ \\
\hline & 3- Parçalanmış Aile & 26 & 32.23 & 7.99 & Gruplar İçi & 7866.448 & 246 & 31.977 & & \\
\hline & 1- Çekirdek Aile & 8 & 36.00 & 4.66 & Toplam & 8084.096 & 248 & & & \\
\hline & 2- Geniş Aile & & \multicolumn{8}{|c|}{ Farkın Kaynağı (Scheffe): 2>1 } \\
\hline \multirow{3}{*}{ Toplam } & 3- Parçalanmış Aile & 215 & 121.39 & 9.43 & Gruplar Aras1 & 169.814 & 2 & 84.907 & .960 & .384 \\
\hline & 1- Çekirdek Aile & 26 & 118.73 & 9.43 & Gruplar İçi & 21754.074 & 246 & 88.431 & & \\
\hline & 2- Geniş Aile & 8 & 122.00 & 8.37 & Toplam & 21923.888 & 248 & & & \\
\hline
\end{tabular}


Tablo 6 incelendiğinde, sosyal bilgiler öğretmen adaylarının aile tipi ile kadın algısı düzeyleri arasında, Kadına Yönelik Ön Kabuller $\left(\mathrm{F}_{(2-246)}=1.745 ; \mathrm{p}>.05\right)$, Kadının Toplumsal Yaşamdaki Kazanımları $\left(\mathrm{F}_{(2-}\right.$ 246) $=.550 ; \mathrm{p}>.05)$, Kadının Toplumsal Yaşamdaki Kayıpları $\left(\mathrm{F}_{(2-246)}=.104 ; \mathrm{p}>.05\right)$, faktörlerinde ve ölçeğin genelinde toplam puan açısından $\left(\mathrm{F}_{(2-24)}=.960 ; \mathrm{p}>.05\right)$ faktörlerinde anlamlı bir farklılık bulunmazken; Türkiye'de Kadının Statüsü $\left(\mathrm{F}_{(2-246)}=3.151 ; \mathrm{p} \leq .05\right)$ ve Kadınların Yaşadıkları Sorunlarla İlgili Çözüm Önerileri $\left(\mathrm{F}_{(2-246)}=3.403 ; \mathrm{p} \leq .05\right)$ faktörlerinde anlamlı farklılık olduğu görülmektedir. Elde edilen sonuçlar doğrultusunda sosyal bilgiler öğretmen adaylarının kadın algıları Türkiye'de Kadın Statüsü faktöründe Geniş Aile Tipinde yetişen sosyal bilgiler öğretmen adaylarının kadın algılarının Çekirdek Aile Tipinde yetişen öğretmen adaylarına kıyasla daha yüksek olduğu görülmektedir. Kadınların Yaşadıkları Sorunlarla İlgili Çözüm Önerileri faktöründe ise Çekirdek Aile Tipinde yetişen sosyal bilgiler öğretmen adaylarının kadın algılarının Geniş Aile Tipinde Yetişen sosyal bilgiler öğretmen adaylarından daha yüksek olduğu sonucuna ulaşılmıştır. Sosyal bilgiler öğretmen adaylarının kadın algısı düzeyleri ile parçalanmış aile yapısı arasında istatistiksel açıdan anlamlı bir farklılığın olmadığı sonucuna ulaşılmıştır. Bu kapsamda parçalanmış aile düzeyinin öğretmen adaylarının kadına yönelik algıları üzerinde bir etki meydana getirmediği söylenebilir.

\section{Altınc1. Alt Probleme İlişkin Bulgular}

Tablo 7. Sosyal Bilgiler Öğretmen Adaylarmm Kadm Algılarnna İliskin Ölçek Ortalamalarmm Doğum Yeri Değiskenine Göre One-Way ANOV A Sonuclar

\begin{tabular}{|c|c|c|c|c|c|c|c|c|c|c|}
\hline Faktör & $\begin{array}{c}\text { Doğum } \\
\text { Yeri }\end{array}$ & $\mathbf{n}$ & $\bar{X}$ & Ss & VK & KT & sd & KO & $\mathbf{F}$ & $\mathrm{p}$ \\
\hline \multirow{4}{*}{$\begin{array}{l}\text { Kadına } \\
\text { Yönelik } \\
\text { Ön Kabuller }\end{array}$} & $1-\dot{\mathrm{Il}}$ & 106 & 31.60 & 3.81 & Gruplar Aras1 & 178.908 & 2 & 178.908 & 4.907 & $.008^{*}$ \\
\hline & 2- İlçe & 123 & 30.98 & 4.09 & Gruplar İçi & 4484.835 & 246 & 4484.835 & & \\
\hline & 3-Köy & 20 & 28.35 & 6.97 & Toplam & 4663.743 & 248 & & & \\
\hline & & & \multicolumn{8}{|c|}{ Farkın Kaynağı (Scheffe): $1>3 ; 2>3$} \\
\hline \multirow{3}{*}{$\begin{array}{l}\text { Kadinın } \\
\text { Toplumsal } \\
\text { Yaşamdaki } \\
\text { Kazanımları }\end{array}$} & 1- $\dot{\mathrm{Il}}$ & 106 & 22.63 & 4.46 & Gruplar Aras1 & 108.904 & 2 & 54.452 & \multirow[t]{3}{*}{2.555} & \multirow[t]{3}{*}{.080} \\
\hline & 2- İlçe & 123 & 22.53 & 4.63 & Gruplar İçi & 5241.851 & 246 & 21.308 & & \\
\hline & 3-Köy & 20 & 20.15 & 5.33 & Toplam & 5350.755 & 248 & & & \\
\hline \multirow{3}{*}{$\begin{array}{l}\text { Kadının } \\
\text { Toplumsal } \\
\text { Yaşamdaki } \\
\text { Kayıpları }\end{array}$} & $1-\dot{\mathrm{Il}}$ & 106 & 18.72 & 4.05 & Gruplar Aras1 & 107.845 & 2 & 53.922 & \multirow[t]{3}{*}{2.617} & \multirow[t]{3}{*}{.075} \\
\hline & 2- İlçe & 123 & 19.97 & 4.84 & Gruplar İçi & 5068.179 & 246 & 20.602 & & \\
\hline & 3-Köy & 20 & 20.40 & 5.06 & Toplam & 5176.024 & 248 & & & \\
\hline \multirow{4}{*}{$\begin{array}{l}\text { Türkiye'de } \\
\text { Kadın } \\
\text { Statüsü }\end{array}$} & $1-$ Il & 106 & 12.34 & 4.73 & Gruplar Aras1 & 364.823 & 2 & 182.412 & \multirow[t]{4}{*}{7.494} & \multirow[t]{4}{*}{$.001^{*}$} \\
\hline & 2- İlçe & 123 & 13.55 & 4.95 & Gruplar İçi & 5987.980 & 246 & 24.341 & & \\
\hline & 3-Köy & 20 & 16.90 & 5.88 & Toplam & 6352.803 & 248 & & & \\
\hline & & & & & Farkın I & nağ1 (Sche & ): 3> & $3>2$ & & \\
\hline \multirow{4}{*}{$\begin{array}{l}\text { Kadınların } \\
\text { Yaşadıkları } \\
\text { Sorunlarla İlgili } \\
\text { Çözüm } \\
\text { Önerileri }\end{array}$} & $1-\dot{\mathrm{Il}}$ & 106 & 35.38 & 5.50 & Gruplar Aras1 & 78.693 & 2 & 39.346 & \multirow[t]{4}{*}{1.209} & \multirow[t]{4}{*}{.300} \\
\hline & 2- İlçe & 123 & 34.84 & 5.35 & Gruplar İçi & 8005.404 & 246 & 32.542 & & \\
\hline & 3-Köy & 20 & 33.25 & 8.37 & Toplam & 8084.096 & 248 & & & \\
\hline & & & & & & & & & & \\
\hline \multirow{3}{*}{ Toplam } & $1-\dot{\mathrm{Il}}$ & 106 & 120.67 & 7.76 & Gruplar Aras1 & 174.844 & 2 & 87.422 & \multirow[t]{3}{*}{.989} & \multirow[t]{3}{*}{.373} \\
\hline & 2- İlçe & 123 & 121.86 & 9.97 & Gruplar İçi & 21749.044 & 246 & 88.411 & & \\
\hline & 3-Köy & 20 & 119.05 & 13.20 & Toplam & 21923.888 & 248 & & & \\
\hline
\end{tabular}

Tablo 7 incelendiğinde, sosyal bilgiler öğretmen adaylarının doğum yeri özellikleri ile kadın algisı düzeyleri arasında, Kadının Toplumsal Yaşamdaki Kazanımları $\left(\mathrm{F}_{(2-246)}=2.555 ; \mathrm{p}>.05\right)$, Kadının Toplumsal Yaşamdaki Kayıpları $\left(\mathrm{F}_{(2-246)}=2.617\right.$; p $>$.05) Kadınların Yaşadıkları Sorunlarla İlgili Çözüm Önerileri $\left(\mathrm{F}_{(2-}\right.$ 246) $=1.209 ; \mathrm{p}>.05)$ faktörlerinde ve ölçeğin genelinde toplam puan açısindan $\left(\mathrm{F}_{(2-246)}=.989 ; \mathrm{p}>.05\right)$ faktörlerinde anlamlı bir farklılık bulunmazken; Kadına Yönelik Ön Kabuller $\left(\mathrm{F}_{(2-246)}=4.907 ; \mathrm{p} \leq .05\right)$ ve Türkiye'de Kadının Statüsü $\left(\mathrm{F}_{(2-246)}=7.494 ; \mathrm{p} \leq .05\right)$ faktörlerinde doğum yeri değişkenine göre anlamlı bir farklılık olduğu görülmüştür. Kadına Yönelik Ön Kabuller faktöründe doğum yeri il ve ilçe olan sosyal bilgiler öğretmen adaylarının kadın algıları doğum yeri köy olan öğretmen adaylarına kıyasla daha yüksek olduğu sonucuna ulaşılmıştır. Türkiye'de Kadın Statüsü faktör boyutunda ise Doğum Yeri köy olan öğretmen adaylarının, doğum yeri il ve ilçe olan öğretmen adaylarına kıyasla kadın algılarının daha yüksek olduğu sonucuna ulaşlmıştır. 


\section{Yedinci Alt Probleme İlişkin Bulgular}

Tablo 8. Sosyal Bilgiler Öğretmen Adaylarmm Kadın Algularına İlişkin Ölçek Ortalamalarmmn Yerleşim Yeri Değiskenine Göre One-W ay ANOVA Sonuclar

\begin{tabular}{|c|c|c|c|c|c|c|c|c|c|c|}
\hline Faktör & $\begin{array}{c}\text { Yerleşim } \\
\text { Yeri }\end{array}$ & $\mathbf{n}$ & $\bar{X}$ & Ss & VK & KT & sd & KO & $\mathbf{F}$ & $\mathrm{p}$ \\
\hline \multirow{4}{*}{$\begin{array}{l}\text { Kadina } \\
\text { Yönelik } \\
\text { Ön Kabuller }\end{array}$} & $1-\dot{\mathrm{Il}}$ & 106 & 31.36 & 4.12 & Gruplar Aras1 & 116.655 & 2 & 58.328 & \multirow{4}{*}{3.156} & \multirow{4}{*}{$.044 *$} \\
\hline & 2- İlçe & 90 & 31.42 & 3.71 & Gruplar İçi & 4547.088 & 246 & 18.484 & & \\
\hline & 3-Köy & 53 & 29.72 & 5.45 & Toplam & 4663.743 & 248 & & & \\
\hline & & & \multicolumn{6}{|c|}{ Farkın Kaynağı (Scheffe): $1>3 ; 2>3$} & & \\
\hline \multirow{3}{*}{$\begin{array}{l}\text { Kadının } \\
\text { Toplumsal } \\
\text { Yaşamdaki } \\
\text { Kazanımları }\end{array}$} & $1-\dot{\mathrm{Il}}$ & 106 & 22.83 & 4.70 & Gruplar Aras1 & 37.787 & 2 & 18.894 & \multirow{3}{*}{.875} & \multirow{3}{*}{.418} \\
\hline & 2- İlçe & 90 & 22.10 & 4.70 & Gruplar İçi & 5312.968 & 246 & 21.597 & & \\
\hline & 3-Köy & 53 & 21.96 & 4.43 & Toplam & 5350.755 & 248 & & & \\
\hline \multirow{3}{*}{$\begin{array}{l}\text { Kadının } \\
\text { Toplumsal } \\
\text { Yaşamdaki } \\
\text { Kayıpları }\end{array}$} & $1-\dot{\mathrm{Il}}$ & 106 & 18.93 & 4.39 & Gruplar Aras1 & 116.562 & 2 & 58.281 & \multirow{3}{*}{2.834} & \multirow{3}{*}{.061} \\
\hline & 2- İlçe & 90 & 19.36 & 4.95 & Gruplar İçi & 5059.462 & 246 & 20.567 & & \\
\hline & 3-Köy & 53 & 20.74 & 4.05 & Toplam & 5176.024 & 248 & & & \\
\hline \multirow{4}{*}{$\begin{array}{l}\text { Türkiye'de } \\
\text { Kadin } \\
\text { Statüsü }\end{array}$} & 1- İl & 106 & 12.53 & 4.80 & Gruplar Aras1 & 281.396 & 2 & 140.698 & \multirow{4}{*}{5.701} & \multirow{4}{*}{$.004 *$} \\
\hline & 2- İlçe & 90 & 13.04 & 4.81 & Gruplar İçi & 6071.407 & 246 & 24.681 & & \\
\hline & 3-Köy & 53 & 15.30 & 5.53 & Toplam & 6352.803 & 248 & & & \\
\hline & & & & & Farkın & nağ1 (Sche & $: 3>1$ & $3>2$ & & \\
\hline \multirow{4}{*}{$\begin{array}{l}\text { Kadınların } \\
\text { Yaşadıkları } \\
\text { Sorunlarla } \\
\text { İlgili Çözüm } \\
\text { Önerileri }\end{array}$} & $1-\dot{\mathrm{Il}}$ & 106 & 35.69 & 4.71 & Gruplar Aras1 & 393.707 & 2 & 196.853 & \multirow{4}{*}{6.297} & \multirow{4}{*}{$.002 *$} \\
\hline & 2- İlçe & 90 & 35.48 & 5.09 & Gruplar İçi & 7690.390 & 246 & 31.262 & & \\
\hline & 3-Köy & 53 & 32.53 & 7.67 & Toplam & 8084.096 & 248 & & & \\
\hline & & & & & Farkın & nağı (Sche & $.1>3$ & & & \\
\hline \multirow{3}{*}{ Toplam } & $1-\dot{\mathrm{Il}}$ & 106 & 121.34 & 9.75 & Gruplar Aras1 & 52.703 & 2 & 26.351 & \multirow{3}{*}{.296} & \multirow{3}{*}{.744} \\
\hline & 2- İlçe & 90 & 121.40 & 8.92 & Gruplar İçi & 21871.185 & 246 & 88.907 & & \\
\hline & 3-Köy & 53 & 120.25 & 9.63 & Toplam & 21923.888 & 248 & & & \\
\hline
\end{tabular}

${ }^{*} \mathrm{p} \leq .05$

Tablo 8 incelendiğinde, sosyal bilgiler öğretmen adaylarının yerleşim yeri özellikleri ile kadın algıs1 düzeyleri arasında, Kadının Toplumsal Yaşamdaki Kazanımları $\left(\mathrm{F}_{(2-246)}=.875 ; \mathrm{p}>.05\right)$, Kadının Toplumsal Yaşamdaki Kayıpları $\left(\mathrm{F}_{(2-246)}=2.834\right.$; p $>$.05) faktörlerinde ve ölçeğin genelinde toplam puan açısından $\left(\mathrm{F}_{(2-}\right.$ 246) $=.296 ; \mathrm{p}>.05)$ faktörlerinde anlamlı bir farklılık bulunmazken; Kadına Yönelik Ön Kabuller ( $\mathrm{F}_{(2-}$ 246) $=3.156 ; \mathrm{p} \leq .05)$ ve Türkiye'de Kadının Statüsü $\left(\mathrm{F}_{(2-246)}=5.701 ; \mathrm{p} \leq .05\right)$ ve Kadınların Yaşadıkları Sorunlarla İlgili Çözüm Önerileri $\left(\mathrm{F}_{(2-246)}=6.297\right.$; $\left.\mathrm{p} \leq .05\right)$ faktörlerinde doğum yeri değişkenine göre anlaml bir farklılık olduğu görülmüştür. Kadına Yönelik Ön Kabuller ve Kadınların Yaşadıkları Sorunlarla İlgili Çözüm Önerileri faktörlerinde yerleşim yeri il ve ilçe olan sosyal bilgiler öğretmen adaylarının kadın algıları yerleşim yeri köy olan öğretmen adaylarına kıyasla daha yüksek olduğu sonucuna ulaşılmıştır. Türkiye'de Kadın Statüsü faktör boyutunda ise yerleşim yeri köy olan öğretmen adaylarının, yerleşim yeri il ve ilçe olan öğretmen adaylarına kıyasla kadın algılarının daha yüksek olduğu sonucuna ulaşılmıştır.

\section{Sekizinci Alt Probleme İlişkin Bulgular}

Tablo 9 incelendiğinde, sosyal bilgiler öğretmen adaylarının anne eğitim düzeyi özellikleri ile kadın alg1sı düzeyleri arasında, Kadına Yönelik Ön Kabuller $\left(\mathrm{F}_{(5-243)}=1.432 ; \mathrm{p}>.05\right)$, Kadının Toplumsal Yaşamdaki Kazanımları $\left(\mathrm{F}_{(5-243)}=.671 ; \mathrm{p}>.05\right)$, Kadının Toplumsal Yaşamdaki Kayıpları $\left(\mathrm{F}_{(5-243)}=1.273\right.$; p>.05), Türkiye'de Kadının Statüsü $\left(\mathrm{F}_{(5-243)}=1.466 ; \mathrm{p}>.05\right)$, Kadınların Yaşadıkları Sorunlarla İlgili Çözüm Önerileri $\left(\mathrm{F}_{(5-243)}=1.236\right.$; p>.05) faktörlerinde ve ölçeğin genelinde toplam puan açısından $\left(\mathrm{F}_{(5-243)}=.893\right.$; p>.05) ve faktörlerinde anne eğitim düzeyi değişkenine göre anlamlı bir farklılık olmadığı görülmüştür. 
Tablo 9. Sosyal Bilgiler Öğretmen Adaylarmmn Kadm Algısı Düzeylerine İlişlein Ölçek Ortalamalarmm Anne Ë̆gitim Düreyi Değģskenine Göre One-Way ANOV A Sonuclar

\begin{tabular}{|c|c|c|c|c|c|c|c|c|c|c|}
\hline Faktör & $\begin{array}{l}\text { Anne Eğitim } \\
\text { Düzeyi }\end{array}$ & $\mathbf{n}$ & $\bar{X}$ & Ss & VK & KT & sd & KO & F & $\mathrm{p}$ \\
\hline $\begin{array}{l}\text { Kadına } \\
\text { Yönelik Ön } \\
\text { Kabuller }\end{array}$ & $\begin{array}{l}\text { 1- Okur-Yazar Değil } \\
\text { 2- İlkokul } \\
\text { 3- Ortaokul } \\
\text { 4- Lise } \\
\text { 5- Ön Lisans } \\
\text { 6- Lisans }\end{array}$ & $\begin{array}{c}17 \\
148 \\
43 \\
31 \\
4 \\
6 \\
\end{array}$ & $\begin{array}{l}29.00 \\
31.14 \\
30.51 \\
32.00 \\
33.25 \\
31.50 \\
\end{array}$ & $\begin{array}{l}6.10 \\
4.16 \\
4.80 \\
3.47 \\
2.36 \\
3.15 \\
\end{array}$ & $\begin{array}{l}\text { Gruplar Arası } \\
\text { Gruplar İçi } \\
\text { Toplam }\end{array}$ & $\begin{array}{c}133.451 \\
4530.291 \\
4663.743\end{array}$ & $\begin{array}{c}5 \\
243 \\
248\end{array}$ & $\begin{array}{l}26.690 \\
18.643\end{array}$ & 1.432 & .213 \\
\hline $\begin{array}{l}\text { Kadının } \\
\text { Toplumsal } \\
\text { Yaşamdaki } \\
\text { Kazanımları }\end{array}$ & $\begin{array}{l}\text { 1- Okur-Yazar Değil } \\
\text { 2- İlkokul } \\
\text { 3- Ortaokul } \\
\text { 4- Lise } \\
\text { 5- Ön Lisans } \\
\text { 6- Lisans } \\
\end{array}$ & $\begin{array}{c}17 \\
148 \\
43 \\
31 \\
4 \\
6 \\
\end{array}$ & $\begin{array}{l}22.82 \\
22.32 \\
21.65 \\
23.00 \\
25.25 \\
22.83 \\
\end{array}$ & $\begin{array}{l}4.97 \\
4.35 \\
5.14 \\
4.90 \\
5.74 \\
5.95 \\
\end{array}$ & $\begin{array}{l}\text { Gruplar Arası } \\
\text { Gruplar İçi } \\
\text { Toplam }\end{array}$ & $\begin{array}{c}72.859 \\
5277.896 \\
5350.755\end{array}$ & $\begin{array}{c}5 \\
243 \\
248\end{array}$ & $\begin{array}{l}14.572 \\
21.720\end{array}$ & .671 & .646 \\
\hline $\begin{array}{l}\text { Kadının } \\
\text { Toplumsal } \\
\text { Yaşamdaki } \\
\text { Kayıpları }\end{array}$ & $\begin{array}{l}\text { 1- Okur-Yazar Değil } \\
\text { 2- İlkokul } \\
\text { 3- Ortaokul } \\
\text { 4- Lise } \\
\text { 5- Ön Lisans } \\
\text { 6- Lisans }\end{array}$ & $\begin{array}{c}17 \\
148 \\
43 \\
31 \\
4 \\
6\end{array}$ & $\begin{array}{l}18.18 \\
19.95 \\
19.47 \\
18.61 \\
17.50 \\
17.17\end{array}$ & $\begin{array}{l}4.95 \\
4.56 \\
4.21 \\
4.90 \\
3.11 \\
4.67\end{array}$ & $\begin{array}{l}\text { Gruplar Arası } \\
\text { Gruplar İçi } \\
\text { Toplam }\end{array}$ & $\begin{array}{c}132.100 \\
5043.924 \\
5176.024\end{array}$ & $\begin{array}{c}5 \\
243 \\
248\end{array}$ & $\begin{array}{l}26.420 \\
20.757\end{array}$ & 1.273 & .276 \\
\hline $\begin{array}{l}\text { Türkiye'de } \\
\text { Kadın } \\
\text { Statüsü }\end{array}$ & $\begin{array}{l}\text { 1- Okur-Yazar Değil } \\
\text { 2- İlkokul } \\
\text { 3- Ortaokul } \\
\text { 4- Lise } \\
\text { 5- Ön Lisans } \\
\text { 6- Lisans }\end{array}$ & $\begin{array}{c}17 \\
148 \\
43 \\
31 \\
4 \\
6\end{array}$ & $\begin{array}{l}13.53 \\
13.75 \\
13.37 \\
11.10 \\
12.25 \\
13.33\end{array}$ & $\begin{array}{l}6.38 \\
5.11 \\
5.00 \\
3.70 \\
1.26 \\
6.50\end{array}$ & $\begin{array}{l}\text { Gruplar Arası } \\
\text { Gruplar İçi } \\
\text { Toplam }\end{array}$ & $\begin{array}{c}185.978 \\
6166.825 \\
6352.803\end{array}$ & $\begin{array}{c}5 \\
243 \\
248\end{array}$ & $\begin{array}{l}37.196 \\
25.378\end{array}$ & 1.466 & .202 \\
\hline $\begin{array}{l}\text { Kadınların } \\
\text { Yaşadıkları } \\
\text { Sorunlarla } \\
\text { İlgili } \\
\text { Çözüm } \\
\text { Önerileri }\end{array}$ & $\begin{array}{l}\text { 1- Okur-Yazar Değil } \\
\text { 2- İlkokul } \\
\text { 3- Ortaokul } \\
\text { 4- Lise } \\
\text { 5- Ön Lisans } \\
\text { 6- Lisans }\end{array}$ & $\begin{array}{c}17 \\
148 \\
43 \\
31 \\
4 \\
6\end{array}$ & $\begin{array}{l}34.35 \\
34.50 \\
35.49 \\
36.74 \\
37.25 \\
32.67 \\
\end{array}$ & $\begin{array}{c}6.15 \\
5.73 \\
5.81 \\
2.89 \\
2.22 \\
12.45 \\
\end{array}$ & $\begin{array}{l}\text { Gruplar Arası } \\
\text { Gruplar İçi } \\
\text { Toplam }\end{array}$ & $\begin{array}{c}200.451 \\
7883.645 \\
8084.096\end{array}$ & $\begin{array}{c}5 \\
243 \\
248\end{array}$ & $\begin{array}{l}40.090 \\
32.443\end{array}$ & 1.236 & .293 \\
\hline Toplam & $\begin{array}{l}\text { 1- Okur-Yazar Değil } \\
\text { 2- İlkokul } \\
\text { 3- Ortaokul } \\
\text { 4- Lise } \\
\text { 5- Ön Lisans } \\
\text { 6- Lisans }\end{array}$ & $\begin{array}{c}17 \\
148 \\
43 \\
31 \\
4 \\
6\end{array}$ & $\begin{array}{l}117.88 \\
121.65 \\
120.49 \\
121.45 \\
125.50 \\
117.50\end{array}$ & $\begin{array}{c}9.44 \\
9.05 \\
10.73 \\
9.08 \\
6.25 \\
11.29\end{array}$ & $\begin{array}{l}\text { Gruplar Arası } \\
\text { Gruplar İçi } \\
\text { Toplam }\end{array}$ & $\begin{array}{c}395.472 \\
21528.416 \\
21923.888\end{array}$ & $\begin{array}{c}5 \\
243 \\
248\end{array}$ & $\begin{array}{l}79.094 \\
88.594\end{array}$ & .893 & .487 \\
\hline
\end{tabular}

\section{Dokuzuncu Alt Probleme İlişkin Bulgular}

Tablo 10 incelendiğinde, sosyal bilgiler öğretmen adaylarının baba eğitim düzeyi değişkeni ile kadın algısı düzeyleri arasında, Kadına Yönelik Ön Kabuller $\left(\mathrm{F}_{(6-242)}=1.756 ; \mathrm{p}>.05\right)$, Kadının Toplumsal Yaşamdaki Kazanımları $\left(\mathrm{F}_{(6-242)}=1.952 ; \mathrm{p}>.05\right)$, Türkiye'de Kadının Statüsü $\left(\mathrm{F}_{(6-242)}=1.239 ; \mathrm{p}>.05\right)$, Kadınların Yaşadıkları Sorunlarla İlgili Çözüm Önerileri $\left(\mathrm{F}_{(6-242)}=.575 ; \mathrm{p}>.05\right)$ faktörlerinde ve ölçeğin genelinde toplam puan açısından $\left(\mathrm{F}_{(6-242)}=.779 ; \mathrm{p}>.05\right)$ ve faktörlerinde baba eğitim düzeyi değişkenine göre anlamlı bir farklılık olmadığı görülmüsstür. Kadının Toplumsal Yaşamdaki Kayıpları $\left(\mathrm{F}_{(6-242)}=2.437\right.$; $\mathrm{p} \leq .05)$ faktör boyutunda ise anlamlı farklılık olduğu görülmüştür. Elde edilen sonuçlar doğrultusunda sosyal bilgiler öğretmen adaylarının Toplumsal Yaşamdaki Kayıpları faktör boyutunda, baba eğitim düzeyi değişkeninde baba eğitim düzeyi ilkokul olan sosyal bilgiler öğretmen adaylarının kadın algıları ortaokul, lise ve yüksek lisans eğitim düzeyine sahip olan öğretmen adaylarına kiyasla daha yüksek olduğu sonucuna ulaşılmıştır. Ayrıca baba eğitim düzeyi ön lisans olan öğretmen adaylarının, baba eğitim düzeyi yüksek lisans olan öğretmen adaylarından daha yüksek olduğu sonucuna ulaşılmıştır. 
Tablo 10. Sosyal Bilgiler Öğretmen Adaylarmın Kadın Algısı Düzeylerine İlişkin Ölçek Ortalamalarmm Baba Ë̆itim Düzeyi Değiskenine Göre One-Way ANOV A Sonuclar

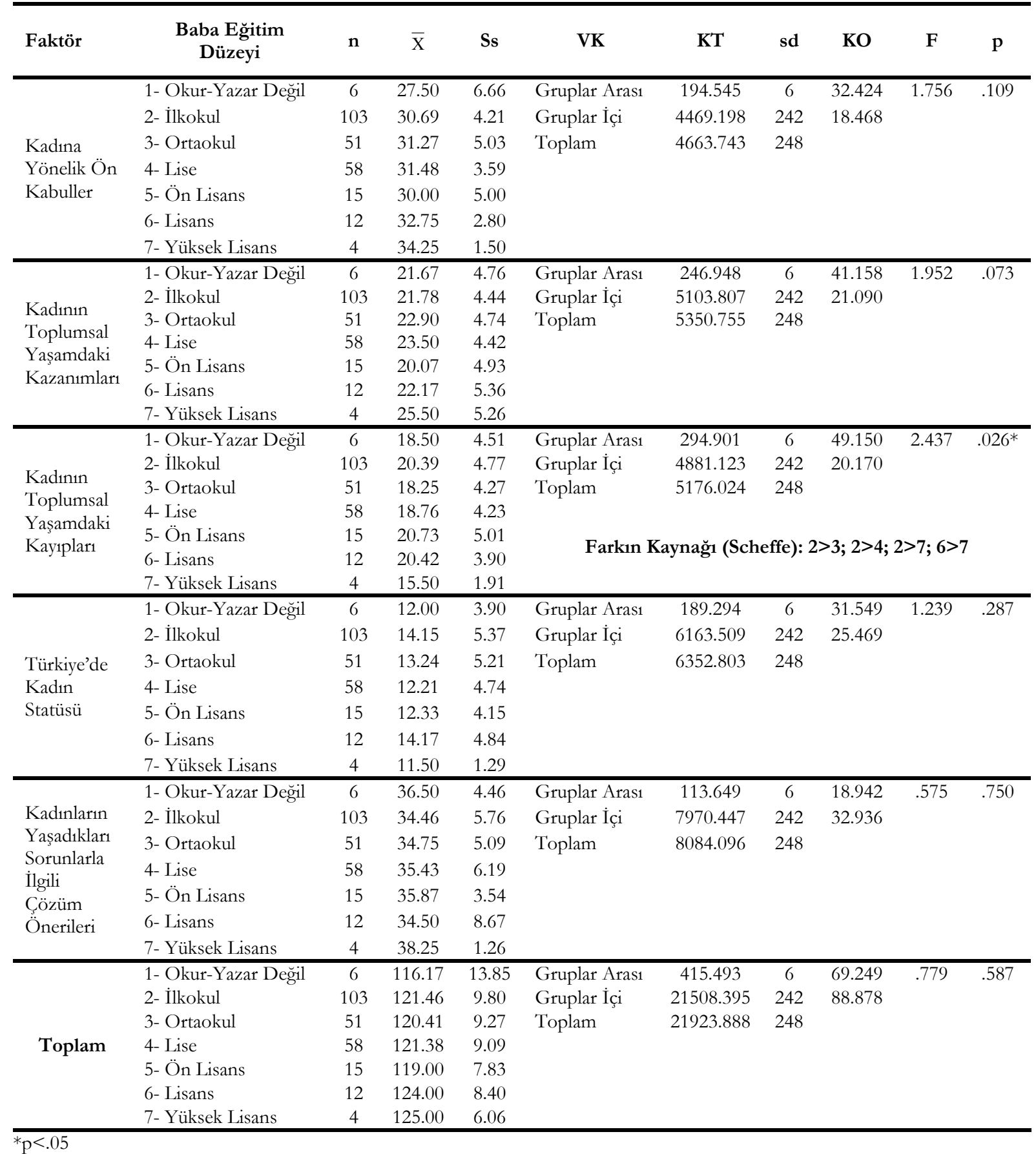

\section{Onuncu Alt Probleme İlişkin Bulgular}

Tablo 11 incelendiğinde, sosyal bilgiler öğretmen adaylarının Anne Meslek Durumu ile kadın algısı alt faktör düzeyleri arasında, Kadına Yönelik Ön Kabuller $\left(\mathrm{t}_{(247)}=.972\right.$; p>.05), Kadının Toplumsal Yaşamdaki Kazanımları ( $\mathrm{t}_{(247)}=.747$; p>.05), Türkiye'de Kadının Statüsü ( $\mathrm{t}_{(247)}=.943$; p>.05), Kadınların Yaşadıkları Sorunlarla İlgili Çözüm Önerileri $\left(\mathrm{t}_{(247)}=.081 ; \mathrm{p}>.05\right)$ faktörlerinde ve ölçeğin genelinde toplam puan açısından $\left(\mathrm{t}_{(247)}=1.770 ; \mathrm{p}>.05\right)$ anlamlı bir farklılı̆̆ın olmadığı görülmüştür. Kadının Toplumsal Yaşamdaki Kayıpları $\left(\mathrm{t}_{(247)}=2.355 ; \mathrm{p} \leq .05\right)$ faktörün de ise anlamlı bir farklılı olduğu görülmüştür. Elde edilen sonuçlar doğrultusunda Kadının Toplumsal Yaşamdaki Kayıpları alt faktöründe annesi çalışmayan öğretmen adaylarının anlamlılık düzeylerinin yüksek olduğu görülmektedir. 
Tablo 11. Sosyal Bilgiler Öğretmen Adaylarmın Kadın Algzlarna İlişkin Ölçek Ortalamalarmm Anne Meslek Durumu Değğskenine Göre Bağımsız. t-Testi Sonuclar

\begin{tabular}{|c|c|c|c|c|c|c|c|}
\hline Faktörler & $\begin{array}{c}\text { Anne } \\
\text { Meslek }\end{array}$ & $\mathbf{n}$ & $\bar{X}$ & Ss & sd & $\mathbf{t}$ & $\mathrm{p}$ \\
\hline \multirow{2}{*}{ Kadına Yönelik Ön Kabuller } & Çalışmıyor & 221 & 31.12 & 4.14 & 247 & .920 & .358 \\
\hline & Çalışıyor & 28 & 30.32 & 5.70 & & & \\
\hline \multirow{2}{*}{$\begin{array}{l}\text { Kadının Toplumsal Yaşamdaki } \\
\text { Kazanımları }\end{array}$} & Çalışmıyor & 221 & 22.30 & 4.61 & 247 & .747 & .456 \\
\hline & Çalışıyor & 28 & 23.00 & 4.95 & & & \\
\hline \multirow{2}{*}{ Kadının Toplumsal Yaşamdaki Kayıpları } & Çalışmıyor & 221 & 19.71 & 4.65 & 247 & 2.355 & $.019 *$ \\
\hline & Çalışıyor & 28 & 17.57 & 3.40 & & & \\
\hline \multirow{2}{*}{ Türkiye'de Kadının Statüsü } & Çalışmıyor & 221 & 13.42 & 5.00 & 247 & .973 & .332 \\
\hline & Çalışıyor & 28 & 12.43 & 5.56 & & & \\
\hline \multirow{2}{*}{$\begin{array}{l}\text { Kadınların Yaşadıkları Sorunlarla İlgili } \\
\text { Çözüm Önerileri }\end{array}$} & Çalışmıyor & 221 & 34.95 & 5.42 & 247 & .081 & .935 \\
\hline & Çalışıyor & 28 & 34.86 & 7.75 & & & \\
\hline \multirow{2}{*}{ Toplam } & Çalışmıyor & 221 & 121.50 & 9.11 & 247 & 1.770 & .078 \\
\hline & Çalışıyor & 28 & 118.18 & 11.21 & & & \\
\hline
\end{tabular}

${ }_{\mathrm{p}} \leq .05$

\section{On Birinci Alt Probleme İlişkin Bulgular}

Tablo 12. Sosyal Bilgiler Öğretmen Adaylarmm Kadın Algzlarna İlişkin Ölçek Ortalamalarmm Baba Meslek Durumu Değişkenine Göre Bağımsız t-Testi Sonuclar

\begin{tabular}{|c|c|c|c|c|c|c|c|}
\hline Faktörler & Baba Meslek & $\mathbf{n}$ & $\bar{X}$ & Ss & sd & $\mathbf{t}$ & $\mathrm{p}$ \\
\hline \multirow{2}{*}{ Kadına Yönelik Ön Kabuller } & Çalışmiyor & 51 & 30.43 & 4.24 & 247 & 1.110 & .268 \\
\hline & Çalışıor & 198 & 31.19 & 4.36 & & & \\
\hline \multirow{2}{*}{ Kadının Toplumsal Yaşamdaki Kazanımları } & Çalışmıyor & 51 & 21.76 & 4.13 & 247 & 1.064 & .288 \\
\hline & Çalışıor & 198 & 22.54 & 4.77 & & & \\
\hline \multirow{2}{*}{ Kadının Toplumsal Yaşamdaki Kayıpları } & Çalışmıyor & 51 & 20.00 & 3.90 & 247 & .929 & .354 \\
\hline & Çalışıyor & 198 & 19.33 & 4.72 & & & \\
\hline \multirow{2}{*}{ Türkiye'de Kadının Statüsü } & Çalışmıyor & 51 & 14.55 & 5.45 & 247 & 1.980 & $.049 *$ \\
\hline & Çalışıyor & 198 & 12.98 & 4.92 & & & \\
\hline \multirow{2}{*}{$\begin{array}{l}\text { Kadınların Yaşadıkları Sorunlarla İlgili } \\
\text { Çözüm Önerileri }\end{array}$} & Çalışmıyor & 51 & 33.37 & 7.26 & 247 & 2.216 & $.028^{*}$ \\
\hline & Çalışıyor & 198 & 35.34 & 5.18 & & & \\
\hline \multirow{2}{*}{ Toplam } & Çalışmıyor & 51 & 120.12 & 7.08 & 247 & .861 & .390 \\
\hline & Çalıșiyor & 198 & 121.39 & 9.91 & & & \\
\hline
\end{tabular}

${ }^{*} \mathrm{p} \leq .05$

Tablo 12 incelendiğinde, sosyal bilgiler öğretmen adaylarının Baba Meslek Durumu ile kadın algisı alt faktör düzeyleri arasında, Kadına Yönelik Ön Kabuller $\left(\mathrm{t}_{(247)}=1.110 ; \mathrm{p}>.05\right)$, Kadının Toplumsal Yaşamdaki Kazanımları ( $\left.\mathrm{t}_{(247)}=1.064 ; \mathrm{p}>.05\right)$, Kadının Toplumsal Yaşamdaki Kayıpları $\left(\mathrm{t}_{(247)}=.929 ; \mathrm{p}>.05\right)$ faktörlerinde ve ölçeğin genelinde toplam puan açısından $\left(\mathrm{t}_{(247)}=.861 ; \mathrm{p}>.05\right)$ anlamlı bir farkliliğın olmadığı görülmüştür. Türkiye'de Kadının Statüsü $\left(\mathrm{t}_{(247)}=1.980 ; \mathrm{p} \leq .05\right)$, Kadınların Yaşadıkları Sorunlarla İlgili Çözüm Önerileri $\left(\mathrm{t}_{(247)}=2.216 ; \mathrm{p} \leq .05\right)$ faktörlerinde ise anlamlı farklllık bulunmuştur. Elde edilen sonuçlar doğrultusunda sosyal bilgiler öğretmen adaylarının kadın algısı anlamlılık düzeyi, Türkiye'de Kadının Statüsü alt faktöründe babası herhangi bir iş kolunda çalışmayan öğretmen adaylarının lehine bir sonuç bulunken; Kadınların Yaşadıkları Sorunlarla İlgili Çözüm Önerileri faktör boyutunda ise babası herhangi bir kolunda çalışan öğretmen adaylarının lehine bir sonuç olduğu görülmektedir.

\section{Tartışma, Sonuç ve Öneriler}

Araştırmadan elde edilen bulgular sonucunda sosyal bilgiler öğretmen adaylarının kadın algılarının yüksek düzeyde olduğu tespit edilmiştir. Bu sonuç doğrultusunda öğretmen adaylarının geleneksel cinsiyet değer ve normları karşısında değişme ve farklılaşmaya yönelik tutum sergiledikleri söylenebilir. Çünkü bir toplumdaki cinsiyete özgü "Kadın ve erkek nasıl olmalıdır? Nasıl konuşmalıdır? Kadınlara ve erkelere özgü giyim tarzı nelerdir?” gibi sorular o toplumun kültürü, değerleri ve geleneklerinin yansıması ile oluşur.

Araştırma kapsamında elde edilen sonuçlar doğrultusunda, sosyal bilgiler öğretmen adayları arasında kadın algısının, cinsiyet değişkeni açısından, kadın adaylarda daha yükssek olduğu sonucuna ulaşılmıştır. Bu sonuç işığında, erkek öğretmen adaylarının geleneksel cinsiyet rollerini benimsediklerini, söylemek mümkündür. Çünkü cinsiyet, hormonların ve genetik özelliklerin toplumsal kuralları uygulama ve bu uygulamalardan alınan dönütlerin bireyin vücudu ve toplum arasındaki ilişkinin bir yansıması olarak 
oluşmaktadır (Aulette, Witner ve Blakely, 2009). Biyolojik özelliklerden çok toplumsal birer kurgu olan kadınlık ve erkeklik (Bora, 2005, s. 22) içselleştirme sonucunda bireyin toplumdaki yeri ve statüsünü de belirlemektedir (Fine, 2015). İlgili alanyazın incelendiğinde; Vefikuluçay, Demirel, Taşkın ve Eroğlu, (2007, s. 32); Yılmaz, Zeyneloğlu, Kocaöz, Kısa, Taşkın ve Eroğlu (2009, s. 781-782); Seçgin ve Tural (2011, s. 2453); Öngen ve Aytaç (2013, s. 9); Seçgin ve Kurnaz (2015, s. 36); Arıc1, (2015, s. 75); Pesen, Kara, Kale ve Abbak. (2016, s. 334) ve Sucu'nun (2019, s. 83) cinsiyet rolleri üzerine yapmı̧ oldukları çalısmalarda da, bu araştırmada elde edilen bulgularla benzer sonuçlara ulaştıkları görülmektedir.

Araşıırma sonucunda elde edilen verilere göre; sosyal bilgiler öğretmen adaylarının kadın algılarının sınıf değişkenine göre istatistiksel açıdan anlamlı düzeyde farklılık gösterdiği tespit edilmiştir. Ölçeğin genelinde ve alt faktörlerde 1., 2., ve 3. sınıfta öğrenim görmekte olan öğretmen adaylarının, kadın algılarının, 4. Sınıfta öğrenim görmekte olan adaylara kıyasla daha yüksek olduğu bulgusuna ulaşılmıştır. Sınıf düzeyine bağlı olarak ulaşılan bu değişmenin sebebi öğretmen adaylarının eğitim süreci içerisinde aldıkları derslerle alakalı olduğu söylenebilir. Aylaz, Güneş, Uzun ve Ünal (2014, s. 185) üniversite öğrencilerinin toplumsal cinsiyet rolüne yönelik görüşlerini inceledikleri araştırmalarında, sınıf düzeyine bağlı olarak anlamlı bir farklılık bulunmadığı bulgusuna ulaşmıştır. Bu sonuçlar üzerinde örneklem gruplarının yaşamlarını sürdürdükleri yerleşim yerinde var olan geleneksel rolleri terk edemedikleri, üniversiteye gelmeden önce aldıkları lise eğitimin etkili olduğu söylenebilir.

Sosyal bilgiler öğretmen adaylarının, araştırmada kullanılan ölçek ve kişisel bilgi formuna verdikleri cevaplar incelendiğinde; ölçeğin genelinde 20 yaş ve 20 yaş altı yaş grubunda yer alan öğretmen adaylarının kadın algılarının daha yüksek olduğu sonucuna ulaşılmıştır. Bu sonuç üzerinde ilgili yaş grubunda, kadınlık ve erkeklik cinsiyet rollerinin yoğun olarak yaşanmasının etkili olduğu söylenebilir. Çünkü cinsiyet rollerinin kabulü ve bu kabulün toplumsallaşma süreci çocukluk çağının ilk dönemlerinde başlamaktadır. Çocukluktan sonraki dönem yani yetişkinlik dönemi ise cinsiyet rollerinin en fazla kabul gördügü ve uygulandığı bir dönemdir. Örneğin bu dönemde kadınların öğretmen veya hemşire gibi toplumda kadınlara özgü görülen mesleklere yönelmeleri, ev işleri ile ilgilenmeleri, çocuk bakımına yardımcı olmaları vb. gibi davranışları gerçekleştirmeleri beklenmektedir (Güldü ve Ersoy Kart, 2009, s. 103; Diekmen, Goodfriend ve Goodwin, 2004, s. 210).

Araştırmanın değişkenlerinden biri olan kardeş sayısı ile sosyal bilgiler öğretmen adaylarının kadın alg1sı düzeyleri arasında anlamlı bir farklılık olmadığı bulgusuna ulaşılmıştır. Elde edilen bu sonuç doğrultusunda sosyal bilgiler öğretmen adaylarının kadın algıları ile kardeş sayısı değişkeni arasında bir ilişki olmadığ1 söylenebilir. Atış da (2010, s. 44) araştırmasında öğrencilerin kardeş sayılarının toplumsal cinsiyet rollerine ilişkin tutumlarını etkilemediği bulgusuna ulaşmıştır. Toplumsal cinsiyet rollerinin kazanılmasında, kardeşin olmaması, kardeş var ise kardeşin-kardeşlerin cinsiyeti etkili olmaktadır. Bu kapsamda Başçı ve Giray (2016, s. 140), Güzel (2016, s. 8), Yıldız ve Keçeci (2016, s. 994), Aydın, Bekar Özen, Yılmaz Gören, ve Sungur (2016, s. 239), Zeyneloğlu (2008, s. 56), Ergin, Bekar ve Acar (2019, s. 127) araştırmalarında kardeş sayısının cinsiyet eşitliği ve cinsiyet rollerinin kazanılmasında etkili olduğunu, bu etkinin cinsiyetlere karşı daha eşitlikçi yaklaşıldığı sonucuna ulaşmışlardır. Aynı şekilde Rust, Golombok, Johnson, Golding ve Alspac (2000, s. 300) araştırmalarında kardeşi olmayan çocukların aynı cinsiyetten kardeşi olanlara göre daha az kalıp yargisal görüşleri olduğu; ancak farklı cinsiyetten kardeşi olanlara göre ise daha fazla kalıp yarg1lı oldukları sonucuna ulaşmışlardır.

Sosyal bilgiler öğretmen adaylarının, aile tipi değişkeni ile kadın algısı düzeyleri arasında, ölçeğin genelinde anlamlı bir farklılık bulunmamıştır. Alanyazın incelendiğinde elde edilen bu bulgu Sucu (2019, s. 58); Atış (2010, s. 47), Arıcı'nın (2011, s. 77) bulgularını desteklemektedir. Ancak; Türkiye'de Kadının Statüsü ve Kadınların Yaşadıkları Sorunlarla İlgili Çözüm Önerileri faktörlerinde, geniş aile tipinde yetişen sosyal bilgiler öğretmen adaylarının kadın algılarının, çekirdek aile tipinde yetişen öğretmen adaylarına kıyasla daha yüksek olduğu bulgusuna ulaşılmıştır. Bu sonuç üzerinde aile içerisinde dağıtılan sorumlulukların, görevlerin ve yapılacak işlerin, geleneksel olarak, cinsiyet gözetilerek dağıtıldığından kaynaklandığı söylenebilir (Şafak, Çopur ve Özkan, 2006, s. 8; Adak, 2007, s. 137)

Araştırmada, sosyal bilgiler öğretmen adaylarının doğum yeri değişkeni ile kadın algısı düzeyleri arasında, ölçeğin genelinde anlamlı bir farklılık bulunmazken; kadına yönelik ön kabuller ve Türkiye'de kadının statüsü faktörlerinde anlamlı bir farklılık olduğu görülmüştür. Bu farkllık; kadına yönelik ön kabuller faktöründe doğum yeri il ve ilçe olan sosyal bilgiler öğretmen adaylarının kadın algılarının, doğum yeri köy olan öğretmen adaylarına kıyasla daha yüksek olduğu yönündedir. Türkiye'de kadın statüsü faktör boyutunda ise doğum yeri köy olan öğretmen adaylarının, doğum yeri il ve ilçe olan öğretmen adaylarına 
kıyasla kadın algılarının daha yüksek olduğu yönündedir. Sosyal bilgiler öğretmen adaylarının yerleşim yeri özellikleri ile kadın algısı düzeyleri arasında, ölçeğin genelinde istatistiksel açıdan bir fark bulunmamıştır. Kadına yönelik ön kabuller, Türkiye'de kadının statüsü ve kadınların yaşadıkları sorunlarla ilgili çözüm önerileri faktörlerinde anlamlı bir farklılık olduğu görülmüştür. Kadına yönelik ön kabuller ve kadınların yaşadıkları sorunlarla ilgili çözüm önerileri faktörlerinde yerleşim yeri il ve ilçe olan sosyal bilgiler öğretmen adaylarının kadın algıları, yerleşim yeri köy olan öğretmen adaylarına kıyasla daha yüksek olduğu belirlenmiştir. Türkiye'de kadın statüsü faktör boyutunda ise yerleşim yeri köy olan öğretmen adaylarının, yerleşim yeri il ve ilçe olan öğretmen adaylarına kıyasla kadın algılarının daha yüksek olduğu sonucuna ulaşılmıştır. Sucu (2019, s. 83) araştırmasında yerleşim yeri değişkeni ile öğretmen adaylarının kadına yönelik algı düzeyleri arasında anlamlı bir farklılık olmadığı bulgusuna ulaşmıştır. Bu sonuçlar üzerinde ailenin, yaşanılan toplumsal çevrenin, kültürel faktörlerin, öğrenilmiş normların ve beklentilerin etkili olduğu söylenebilir. Çünkü kız ve erkek çocukların cinsiyetlerine göre üstlendikleri roller ve edindikleri sorumluluklar ailede ve çevrenin etkisi ile kazanılmakta böylece kadınlık ve erkeklik cinsiyet kimliği oluşmaktadır (Basow, 1992, s. 459; Martin, 2005, s. 476; Dökmen, 2016, s. 180).

Gerçekleştirilen bu araştırmada sosyal bilgiler öğretmen adaylarının kadın algılanı ile anne eğitim düzeyi değişkeni arasında anlamlı bir ilişki olmadığı bulgusuna ulaşılmıştır. Baba eğitim düzeyi değişkeninde ise ölçeğin genelinde anlamlı bir farklılık bulunmazken, Kadının Toplumsal Yaşamdaki Kayıpları faktöründe anlamlı farklılık olduğu bulgusuna ulaşılmıştır. Bu fark; baba eğitim düzeyinin artması ile doğru orantılıdır. Baba eğitim düzeyi arttıkça, sosyal bilgiler öğretmen adaylarının kadın algısının arttı̆̆1 bulgusuna ulaşılmıştır. Bireyler öğrenmelerinin çoğunu ebeveynlerini model alarak gerçekleştirmektedirler. Ebeveynlerin davranışları ve bu davranışların sonuçları, bireyleri geleneksel kadın veya erkek cinsiyet rollerine göre davranmaları veya bu davranışlardan vazgeçmeleri noktasında etkilemektedir (Bussey ve Bandura, 1999, s. 685). Babaların eğitim düzeyinin artması ile aile bireylerinde kadınların toplumsal yaşamdaki yeri noktasında farkındalık oluştuğu söylenebilir.

Araştırmanın alt problemlerinden olan anne meslek durumu değişkeni ile sosyal bilgiler öğretmen adaylarının kadın algıları arasında ölçeğin genelinde anlamlı bir fark bulunmazken, kadının toplumsal yaşamdaki kayıpları faktöründe, annesi çalısmayan öğretmen adayları lehine bir farklılık olduğu belirlenmiştir. Elde edilen bu bulgu, annenin bir kadın olarak çalışmamasının aile içerisinde ve toplumda bir kayıp olarak görüldüğünü göstermesi açısından önemlidir. Baba meslek değişkeninde ise ölçeğin genelinde anlamlı bir fark olmadığı belirlenmiştir. Ancak; Türkiye'de kadının statüsü alt faktöründe, babası herhangi bir iş kolunda çalışmayan öğretmen adaylarının lehine bir sonuca ulaşılmıştır. Yaşadıkları sorunlarla ilgili çözüm önerileri faktör boyutunda ise babası herhangi bir iş kolunda çalışan ögretmen adaylarının kadın algılarının daha yüksek olduğu tespit edilmiştir. Alanyazın incelendiğinde, toplumsal cinsiyet rollerinin araştırıldı̆̆ı çalışmalar olan Yazıcı (2016, s. 850), Yıldız ve Keçeci de (2016, s. 996) çalışmalarında benzer sonuçlar elde etmişlerdir.

Modernliğin ölçütlerinden birisi toplumda kadına verilen değerdir. Tüm toplumlarda değerli olan kadın hak ettiği değeri almasını bilmeli ve erkekler de bu değeri ona vermelidir. Çünkü toplumsal gelişim kadının toplumdaki yerinin kabulü ile başlamaktadır. Türk toplumunda kadınlar öncelikle anne, eş olarak görülmekte; cinsiyetinden dolayı ev ve çocuk işlerinin yüklendiği bireyler olarak algılanmaktadır. Erkeklerin ise bu tip sorumlulukları olmadığı kanısı yaygındır. Toplumsal cinsiyet ilişkilerinde bu tip cinsiyet körlüğü (görmezliği) (Leadbetter, 2004, s. 3) oluşan eşitsizlikleri sürekli hale getirmektedir.

Gelecek nesillerin yaşamını iyileştirmek için doğru seçimlerin bugünden yapılarak hareket edilmesi kaçınılmazdır. Sürdürülebilir bir kalkınmaya ulaşmak, sürdürülebilir bir gelecek inşa etmek için gerekli olan değerlerin, yaşam tarzlarının ve davranışların tüm bireylere öğretilmesi gereklidir. Çocuklarımızın ilk formal eğitmenleri öğretmenleridir. Eğitimden beklenen; stereotipleşmiş yargılardan kurtularak her iki cinsi cinsiyetlere karşı duyarlı olarak yetişmesidir. Kadın ve erkek öğretmenlerin cinsiyet körü olmamaları, sınıflara cinsiyete tarafsız kişiler olarak girmeleri, öğrencilerini geleneksel cinsiyet rolleri kapsamında yetiştirmemeleri beklenmektedir. Elde edilen sonuçlar ışığında şu öneriler getirilebilir:

- Sınıf düzeyinde meydana gelen farkın en aza indirgenebilmesi için sosyal bilgiler lisan eğitiminde, tüm sınıf düzeylerinde cinsiyet eşitliği ve kadın-erkek algısı konusunu içeren bir ders verilmelidir.

- Yaş değişkenine ilişkin farkın en aza indirgenmesi için ilköğretim ve ortaöğretim eğitiminde yer alan müfredatlar ve ders içeriklerinin cinsiyet dostu politikalar ile hazırlanmasına dikkat edilmelidir. 
- Yerleşim yeri değişkenine ilişkin farklar göz önüne alındığında; üniversite öğrenim sürecinden önce ortaöğretim kuramlarında ergenlik sürecinde ve sonrasında bireye cinsiyet eğitimi verilmesi önerilir.

- Literatüre katkı sağlaması amacıyla; araştırmanın farklı örneklem grupları ve farklı değişkenlerle gerçekleştirilmesi önerilir.

\section{Etik Beyan}

"Sosyal Bilgiler Öğretmen Adaylarının Kadına Yönelik. Algularmın Ceşitli Değ̈işkenler Açısından İncelenmesi” başlıklı çalışmanın yazım sürecinde bilimsel, etik ve alınt kurallarına uyulmuş; toplanan veriler üzerinde herhangi bir tahrifat yapılmamış ve bu çalışma herhangi başka bir akademik yayın ortamına değerlendirme için gönderilmemiştir.

\section{Kaynakça}

Acker, S. (1988). Teachers, gender and resistance. British Journal of Sociology of Education. 9(3), 307322.ttp://www.tandfonline.com/doi/abs/10.1080/0142569880090304?journalCode $=$ cbse20, adresinden 01.09.2019 tarihinde erișilmiștir.

Adak, N. (2007). Kadınların ikilemi: iş ve aile yaşamı. Sosyoloji Dergisi, Ülgen Oskay’a Armağan Özel Sayısı (Hakemsiz Say1), 17, 137-152.

Akar, Y. (2018). Erkeklik ve iktidar: erkeklik dinamiklerinin kadina yönelik bakış açısı Eskeişebir'de yașayan göçmenlerin ve tatarlarn kadn algısı. (Yüksek Lisans Tezi). Niğde Ömer Halis Demir Üniversitesi Sosyal Bilimler Enstitüsü, Niğde.

Arıc1, F. (2011). Üniversite ögrencilerinde toplumsal cinsiyet rollerine ilişkin algzlar ve psikolojik iyi oluş. (Yüksek Lisans Tezi). Hacettepe Üniversitesi Sosyal Bilimler Enstitüsü, Ankara.

Atış, F. (2010). Ebelik/ hemşirelik 1. ve 4. sinf ögrencilerinin toplumsal cinsiyet rollerine ilişkin rollerinin belirlenmesi (Yüksek Lisans Tezi). Çukurova Üniversitesi Sağlık Bilimleri Enstitüsü, Adana.

Aydın, M., Bekar Özen, E., Yılmaz Gören, Ş. \& Sungur, M. A. (2016). Hemşirelik öğrencilerinin toplumsal cinsiyet rollerine ilişkin tutumları. AİBÜ Sosyal Bilimler Enstitüsü Dergisi, 16(1), 223-242.

Aylaz, R., Güneş, G., Uzun, Ö. ve Ünal, S. (2014). Üniversite öğrencilerinin toplumsal cinsiyet rolüne yönelik görüşleri. Sürekli Tip Eğitimi Dergisi, 23(5), 183-190.

Basow, S. A. (1992). Gender: stereotypes and roles (3rd ed.) Thomson Brooks/Cole Publishing Co..https://www.worldcat.org/title/gender-stereotypes-and-roles/oclc/647115084 $10.09 .2019 \quad$ tarihinde erişilmiştir.

Başçı B. ve Giray, S. (2016). The survey of multivariate analysis for the undergraduate students'attitudes towards communal gender roles. Journal of Life Economics, 3(4), 117-142.

Bebel, A. (1996). Kadın ve sosyalizm. S. N. Kaya (Çev.). İnter.

Bileşmiş Milletler Kalkınma Programı (UNDP). (2018).http://www.tr.undp.org/content/turkey/tr/home.html adresinden 12.07.2019 tarihinde erișilmiștir.

Biny1l Kalkınma Hedefleri, (2018).http://www.un.org.tr/includes/files/Binyil02.pdf adresinden 28.07.2019 tarihinde erişilmiştir.

Bussey, K. ve Bandura, A. (1999). Social congnetive theory of gender development and differentiation. Psychological Review, 106(4), 676-713.

Connell, R. W. (2016). Toplumsal cinsiyet ve iktidar. İstanbul: Ayrıntı.

Diekmen, A. B., Goodfriend, W. ve Goodwin, S. (2004). Dynamics stereotypes of power: perceived change and stability in gender hierarchies. Sex Roles, 50(3), 201-215.

Dökmen, Z. Y. (2016). Toplumsal cinsiyet, sosyal psikolojik açılamalar (5. Bask1). İstanbul: Remzi.

Ergin, A., Bekar, T. ve Aydemir Acar, G. (2019). Tıp fakültesi öğrencilerinin toplumsal cinsiyet rollerine yönelik tutumlar1 ve etkileyen faktörler. Furat Tip Dergisi, 24(3): 122-128.

Güldü, Ö. ve\& Ersoy Kart, M. (2009). Toplumsal cinsiyet rolleri ve siyasal tutumlar: sosyal psikolojik bir değerlendirme. Ankara Üniversitesi SBF Dergisi, 64(03), 97-116.

Gülmez N., İra N., Yılmaz İ. ve Özenç İra G. (2017). Üniversite öğrencilerinde kadın alg1sı ölçeğinin geçerlik ve güvenirlik çalışması. MCBÜ Sosyal Bilimler Dergisi, 15(1), 65-86.

Güzel, A. (2016). Öğrencilerin toplumsal cinsiyet rolleri tutumları ve ilişkili faktörler. Gümüşhane Üniversitesi Sağhlk Bilimleri Dergisi, 5(4): 1-11.

Kadına Yönelik Şiddetle Mücadele Ulusal Eylem Planı (2016). Kadının Statüsü Genel Müdürlüğü. Ankara.

Kadının Güçlenmesi Strateji Belgesi ve Eylem Planı 2018-2023 (2018). https://kadininstatusu.aile.gov.tr/data/54296c50369dc32358ee2c4f/KADININ\%20G\%C3\%9C\%C3\%87LEN MES\%C4\%B0\%20STRATEJ\%C4\%B0\%20BELGES\%C4\%B0\%20VE\%20EYLEM \%20PLANI\%20(20182023).pdf adresinden 14.05.2019 tarihinde erişilmiştir.

Karasar, N. (2014). Bilimsel araştırma yöntemi (26. Bask1). Ankara: Nobel.

Leadbetter, H. (2004), "Gender budgeting", spectrum, policy \& technical perspectives for cipfa members and students, 4, The Charted Institute of Public Finanace and Accountancy, pp 3-4, London. 
Milli Eğitim Temel Kanunu (2018). http://www.mevzuat.gov.tr/MevzuatMetin/1.5.1739.pdf adresinden 16.05.2018 tarihinde erişilmiştir.

Öngen, B. ve Aytaç, S. (2013). Üniversite öğrencilerinin toplumsal cinsiyet rollerine ilişkin tutumları ve yaşam değerleri ilişkisi. Sosyoloji Konferanslar, 48(2), 1-18.

Özen, Y. ve Gül, A. (2007). Sosyal ve eğitim bilimleri araştırmalarında evren-örneklem sorunu. Atatürk Üniversitesi Ką̧m Karabekir Eğitim Fakültesi Dergisi, (15), 394-422.

Pesen, A., Kara, İ., Kale, M. ve Abbak, B. S. (2016).Üniversite öğrencilerinin toplumsal cinsiyet algısı ile çatışma ve şiddete ilişkin farkındalık düzeylerinin incelenmesi. Uluslararası Toplum Araştırmalar Dergisi, 6(11), 325-339.

Rust, J., Golombok, S., Hines, M., Johnson, K., Golding, J. ve Alspac Study Team. (2000). The role of brothers and sisters in the gender development of preschool children. Journal of Experimental Child Psychology, 77(4), 292-303.

Sarper, D. (2015). Kadın pop star imgeleri ve toplumda kadm algısi: Amerika, İtalya ve Türkiye örneği. Dokuz Eylül Üniversitesi Sosyal Bilimler Enstitüsü. (Yüksek Lisans Tezi). Dokuz Eylül Üniversitesi, Sosyal Bilimler Enstitüsü, İzmir.

Sayılan, F. (2012). Toplumsal cinsiyet ve egitim: olanaklar ve sinirlar. Ankara: Dipnot.

Seçgin, F. ve Kurnaz, Ş. (2015) Sosyal bilgiler dersinde toplumsal cinsiyet etkinliklerinin öğrencilerin alg1 ve tutumlarına etkisi. Uluslararası Türk Eğitim Bilimleri Dergisi, 3(5), 24-38.

Seçgin, F. \& Tural, A. (2011). Sınıf öğretmenliği bölümü öğretmen adaylarının toplumsal cinsiyet rollerine ilişkin tutumlar1. e-Journal of New World Sciences Academy Education Sciences, 6(4), 2446-2458.

Şafak, S., Çopur, Z. ve Özkan, M. (2006). Çocukların evle ilgili faaliyetlere harcadıkları zamanın incelenmesi. Hacettepe Üniversitesi Sosyolojik. Araştırmalar E-Dergisi, 94, http://www.sdergi.hacettepe.edu.tr/makaleler/sszcmao.pdf

Temelkuran, E. (2013). Düğ̈̈mlere üfleyen kadinlar. İstanbul: Everest.

UNICEF (2015). Türkiye Ülke Raporu. http://education-equity.org/wp-content/uploads/2014/02/\%C3\%B6LKERAPORU-Tr-14.1.2014.pdf adresinden 03.05.2019 tarihinde erişilmiştir.

Vefikuluçay, D., Demirel, S., Taşkın, L. ve Eroğlu, K. (2007). Kafkas üniversitesi son sınıf öğrencilerinin toplumsal cinsiyet rollerine ilişkin bakış açıları. Hacettepe Üniversitesi Hemşirelik. Yüksekokulu Dergisi, 14(2), 12-27.

Wollstonecraft, M. (2012). Kadın hakelarmmn gerekçelendirilmesi. Hakyemez D. (Çev.). İstanbul: İşbankası.

Yazıcı, K. (2011). Sosyal bilgiler öğretmen adaylarının demokratik değerlerinin çeşitli değişkenler açısından incelenmesi. Egitim ve Bilim, 36(159), 165-178.

Yazıc1, T. (2016). Müzik öğretmeni adaylarının toplumsal cinsiyet rollerine ilişkin tutumları. Akademike Bakış Dergisi. $54,833-852$

Yıldız, E. ve Keçeci, O. (2016). Ege üniversitesi spor bilimleri fakültesi öğrencilerinin toplumsal cinsiyet rollerine ilişkin bakış açısı. Uluslararası Sosyal Araștırmalar Dergisi, 9(47), 986-998.

Yılmaz, D. V., Zeyneloğlu, S., Kocaöz, S., Kısa, S., Taşkın, L. Ve Eroğlu, K. (2009). Üniversite öğrencilerinin toplumsal cinsiyet rollerine ilişkin görüşleri. Uluslararası Insan Bilimleri Dergisi, 6(1), 775-792.

Zeyneloğlu, S. (2008). Ankara'da hemşirelik ögrenimi gören üniversite ögrencilerinin toplumsal cinsiyet rollerine iliskin tutumlar. (Doktora Tezi). Hacettepe Üniversitesi Sağlık Bilimleri Enstitüsü, Ankara.

\section{EXTENDED ABSTRACT}

Woman; Since the early ages of history, it has been identified with the house, kept away from the public sphere, and the capacity of girls is limited and prevented compared to boys. The women who tried to get out of the darkness of the Middle Ages tried to establish their existence with the age of enlightenment. Emphasizing that women's problem requires special research, Bebel said; She stated that half of humanity is dealing with the questions of what was the place of women, what is today, what will be tomorrow. Women wanted to take part in the French Revolution and the people's council during the Enlightenment period. This request resulted in the execution of the person who voiced the request by the guillotine of Olympe de Gouges. The negativity experienced could not stop women from saying 'I am here. Women who began to gain social rights with the industrial revolution became visible after the 80s. Studies on the history of femininity and the definition of women, which were written with very challenging struggles, have increased since the 20th century. Femininity and masculinity are socially learned stereotypes. To get rid of these stereotypes in the 21st century, countries around the world; issues related to women in management, education, cultural and social dimensions are included in development policies. In this conjuncture, studies are carried out on women in our country. Gender equality is implemented as a state policy and efforts are made to eliminate gender discrimination.

This research is a descriptive study that tries to determine the perceptions of prospective social studies teachers towards women. The research was conducted with relational survey model. "Screening models are research approaches that aim to describe a situation that existed or existed in the past as it exists. The important thing is to be able to 'observe' it appropriately (Karasar, 2014, p. 77). The study group of this research; A total of 249 social studies teacher candidates, 151 females and 98 males, continue 
their education in the Social Sciences Education Department of the Faculty of Education at a state university in the Central Anatolia region. The "Personal Information Form hazırlanan prepared by the researcher and the Kadın Perception of Women in University Students geliştiril developed by Gülmez, İra, Yilmaz and Özenç İra (2017) were used as data collection tools. Cronbach's alpha values obtained by applying the female perception scale to the study group; .75. Gülmez, İra, Yllmaz and Özenç İra's (2017) cronbach alpha internal consistency coefficient obtained from the whole scale is .84. Women's perceptions level scores of social studies teacher candidates were determined with descriptive statistics applications. In the calculation of the arithmetic mean scores of the social studies teacher candidates' answers to the questions in the data collection tool; Never $(1.00<\overline{\mathrm{X}} \leq 1.79)$, Rarely $(1.80<\overline{\mathrm{X}} \leq 2.59)$, Occasionally $(2.60<$ $\bar{X} \leq 3.39)$, Often $(3.40<\bar{X} \leq 4.19)$, Always $(4.20<\bar{X} \leq 5.00)$ ranges.

It was concluded that female perceptions were higher among female teacher candidates in terms of gender variable. In the light of this result, it is possible to say that male teacher candidates adopted traditional gender roles. It was determined that female perceptions of social studies teacher candidates differed statistically according to class variable. In the overall scale and in the sub-factors, it was found that pre-service teachers in the 1st, 2nd, and 3rd grades had higher perceptions of women than in the 4th grade. When the responses of the social studies teacher candidates to the scale and personal information form used in the research were examined; It was found that pre-service teachers in the 20 -year-old and younger age groups had higher female perceptions.

According to the obtained results, it can be said that there is no relationship between the female perceptions of social studies teacher candidates and the number of siblings. When the answers of social studies teacher candidates to the perception of women in university students were examined; There was no significant difference between the family type variable and female perception levels in the overall scale. While there was no significant difference between the place of birth variable and female perception levels of the prospective social studies teachers in the overall scale; Preliminary Assumptions Against Women and the Status of Women in Turkey were found to be a significant difference in the factor. This difference; According to the Pre-Assumptions for Women factor, the female perceptions of social studies teacher whose birth place is province and district are higher than the prospective teachers whose birth place is village. There was no statistically significant difference between the residence characteristics of social studies teacher candidates and women? S perception levels. It was found that there was no significant relationship between female perceptions of social studies teacher candidates and mother education level variable. While there was no significant difference in the father education level variable in the whole scale, it was found that there was a significant difference in the Losses of Women in Social Life factor. This difference; father is directly proportional to the increase in education level. In order to improve the lives of future generations, it is inevitable to make the right choices from today. All individuals should be taught the values, lifestyles and behaviors necessary to achieve sustainable development and build a sustainable future. The first formal trainers of our children are their teachers. 